Historical records of eutrophication

F. Cheng et al.

\title{
Historical records of eutrophication in Changjiang (Yangtze) River estuary and its adjacent East China Sea
}

F. Cheng ${ }^{1,2}$, X. Song ${ }^{1}$, Z. Yu ${ }^{1}$, and D. Liu ${ }^{3}$

${ }^{1}$ Key Laboratory of Marine Ecology and Environmental Sciences, Institute of Oceanology, Chinese Academy of Sciences, 266071 Qingdao, China

${ }^{2}$ Graduate School of the Chinese Academy of Sciences, 100039 Beijing, China

${ }^{3}$ Yantai Institute of Coastal Zone Research for Sustainable Development, Chinese Academy of Sciences, 17 Chunhui Road, 264003 Yantai, China

Received: 22 April 2012 - Accepted: 2 May 2012 - Published: 1 June 2012

Correspondence to: Z. Yu (zyu@qdio.ac.cn)

Published by Copernicus Publications on behalf of the European Geosciences Union.

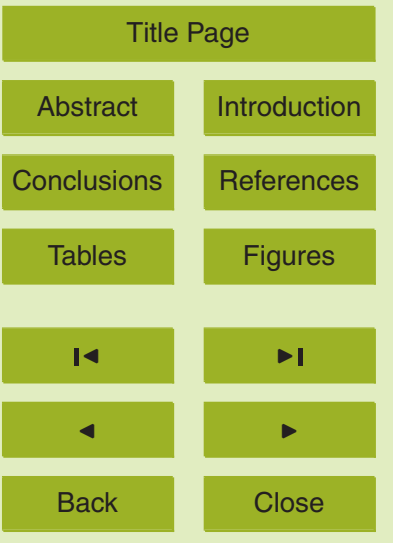

Full Screen / Esc

Printer-friendly Version

Interactive Discussion 


\section{Abstract}

Two sediment cores from the Changjiang (Yangtze) River estuary and its adjacent East China Sea were collected and studied for eutrophication history using paleoecological records of environmental changes over the last century. A multiproxy approach by using 5 biological and geochemical analyses revealed changes in diatom assemblages, total organic carbon (TOC), total nitrogen (TN) and biogenic silica (BSi) and give an indication of nutrient in status and trends in Changjiang River estuary and its adjacent East China Sea. The diatom assemblages in the two cores generally increased gradually from the 1970s, and accelerated from the 1990s until now, reflecting the increased eutrophication and causing large algae blooms/red tides. The TOC, TN and BSi showing the similar trends, supported the interpretation of the eutrophication process indicated by diatom analyses. The two cores were located in different sea areas of the East China Sea, and we discuss their relative changes based on their environment characteristics. We also discuss the potential effect of anthropogenic influences and ongoing projects on eutrophication in the Changjiang River and its adjacent East China Sea.

\section{Introduction}

Coastal waters and estuaries are being threatened by eutrophication, which has been considered as a widespread major problem in marine ecosystems for $40 \mathrm{yr}$ (Ryther and Dunstan, 1971; Nixon, 1995; Elmgren and Larsson, 2001). High rates of nutrient loadings to coastal areas have resulted in enhancement of phytoplankton growth and thus frequently caused algae blooms. Eutrophication has been predicted to increase further in the 21st Century (Nixon, 1995). The different processes and effects of eutrophication in the world are well known and documented (Cloern, 2001; Conley et al., 2002; Ronnberg and Bonsdorff, 2004). In the Changjiang (Yangtze) River estufertilizers, domestic waste and rapid development of industries, especially the fishery

BGD

$9,6261-6291,2012$

\section{Historical records of eutrophication}

F. Cheng et al.

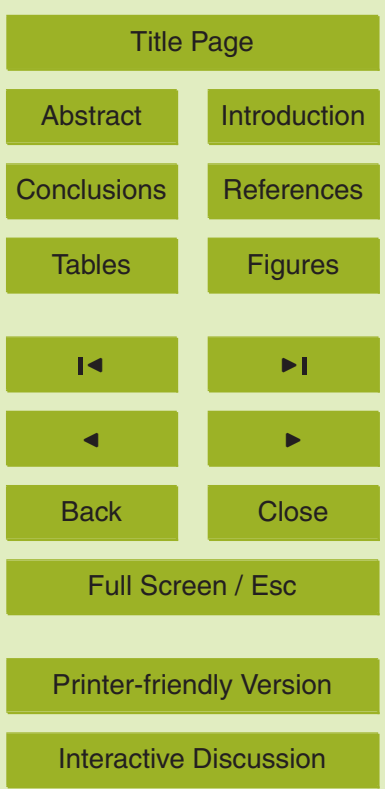

Interactive Discussion 
industry, have led this area receiving high loadings of anthropogenic nutrients and being the most serious eutrophied space in China (State Ocean Administration 2009). The annual river input of dissolved inorganic nitrogen (DIN), phosphorus and silicon was $7.84 \times 10^{5}, 1.51 \times 10^{4}, 2.22 \times 10^{6}$ t, respectively (Shen and Liu, 2009). A high N : P 5 ratio and phosphorus limitation has been observed in surface water in spring (Pu et al., 2001; Chen et al., 2004; Ning et al., 1998). This clearly indicated surplus nitrogen in the discharge water. Frequent algae blooms occurring here due to increased eutrophication has drawn significant attention because of their potential risk to local human health and fishing industries.

10 The temporal and spatial distribution of biologically available inorganic forms of nutrients such as N, P and Si in the aquatic environment and their impact on local ecosystems are the major concern in eutrophication studies. Unfortunately, most marine eutrophication research is based on local field studies lasting only a few years without a longer term historical perspective since marine eutrophication has only been ac15 knowledged seriously since the mid-1980s (Boesch, 2002; Nixon, 1995). Data mining from early monitoring programs and historical records is poor or discontinuity and thus are not sufficient to identify anthropogenic effects on the ecology of coastal areas and unable to answer questions about the eutrophication process on a temporal scale (Billen and Garnier, 1997). In the Changjiang River estuary and its adjacent ECS, the historical data we obtained from the ecological monitoring programs starting from the 1980 s had a problem of temporal discontinuity. Poorly designed programs using inadequate sampling strategies could lead to unreliable data and may not reflect the real environment at that time.

The stratigraphic record embedded in the sediments can be used to provide key information on the timing and magnitude of ecological changes in estuaries and coastal areas (Cooper and Brush, 1993; Zimmerman and Canuel, 2000, 2002; Gooday et al., 2009). Numerous methodologies in sediment analysis can be used for reconstruction of ecological changes. Paleoecological studies provide critical information, including sediment profiles of geochemical indicators, for example: total nitrogen (TN) (Nixon,
BGD

9, 6261-6291, 2012

\section{Historical records of eutrophication}

F. Cheng et al.

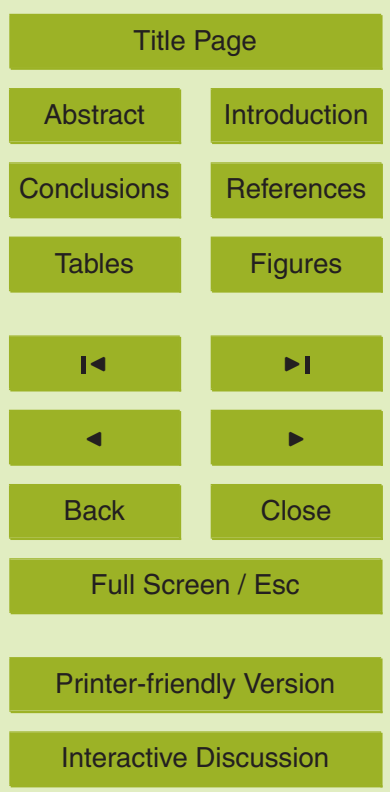


1995), total organic carbon (TOC) (Jonsson and Carman, 1994), stable isotopes (Voß and Struck, 1997), organic phosphorus (Turner, 2009), inositol phosphates (Turner et al., 2002), biogenic silicon (BSi) (Cornwell et al., 1996) and plant pigments and lipids (Ficken and Farrimond, 1995), or interpretations based on biological indicators, 5 such as diatoms (Clarke et al., 2003), dinoflagellate cysts (De Vernal et al., 2007) and foraminifera (Jorissen et al., 2007). Diatoms are useful biological indicators because of their taxonomic distinction, abundance, ubiquity and high preservation in a variety of sedimentary environments due to their siliceous cell walls. As a susceptible indicator in the aquatic environment, diatoms are known to be sensitive to changes in the trophic condition of the environment, and different species have distinct ecological habitats (Charles et al., 1994; Anderson and Vos, 1992; Stoermer and Smol, 1999). There is a long history of using diatoms in ecological change studies in coastal systems (summaried by Stoermer and Smol, 1999) and diatoms have been used as indicators for eutrophication in coastal waters in some areas (Cooper and Brush, 1993; Andren, 15 1999; Liu et al., 2008; Clarke et al., 2006; Tibby and Taffs, 2011).

In this study, we used a multiproxy paleoecological approach to analyse sediment cores from two sites affected by eutrophication in the Changjiang (Yangtze) River estuary and its adjacent ECS in China. On the basis of core chronologies, we present changes in diatom assemblages, including absolute abundance, species richness, diversity and significant species distribution in the two cores, respectively. Proxies of geochemical indicators including total organic carbon (TOC), total nitrogen (TN) and biogenic silica (BSi) were also examined. Thus, through the interpretation of the information given by the these results, we aimed (1) to determine the ecological changes especially the eutrophication history in the Changjiang (Yangtze) River estuary and its adjacent ECS over the last century; (2) to assess the impacts of anthropogenic disturbances on the sedimentary environment. We also compared associated changes for two sites affected by eutrophication. To our knowledge, this is the first report of a multiproxy approach in the paleo-reconstruction of the eutrophication history of the ECS in China.

BGD

9, 6261-6291, 2012

Historical records of eutrophication

F. Cheng et al.

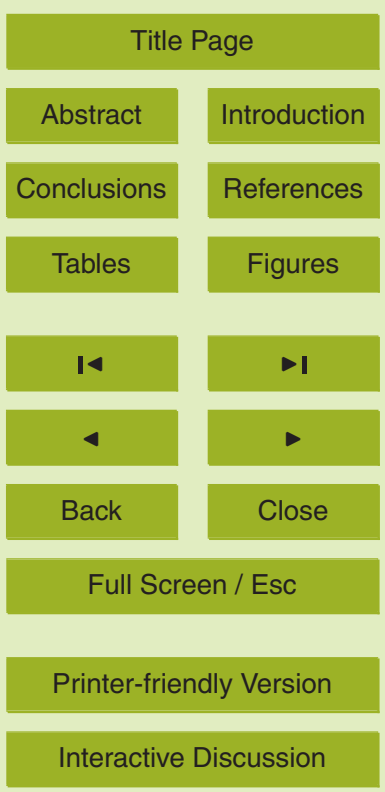

Interactive Discussion 


\section{Materials and methods}

\subsection{Site description}

The ECS $\left(21^{\circ} 54^{\prime} \sim 33^{\circ} 17^{\prime} \mathrm{N}, 117^{\circ} 05^{\prime} \sim 131^{\circ} 03^{\prime} \mathrm{E}\right)$ extending from the mainland China coastal line to the Okinawa Trough and Ryukyu Islands covers an area of $7.7 \times 10^{5} \mathrm{~km}^{2}$.

5 It is the largest marginal sea in the western North Pacific, characterized by dynamic interactions among the water systems including the Changjiang River, the Kuroshio Current and the Taiwan Warm Current (TWC) (Miao and Yu, 1991). On the western side of the ECS, waters are affected by the fresh water runoff from the Changjiang River, the coastal currents along Mainland China (East China Sea Coastal Current, 10 ECSCC), the TWC and a branch of Kuroshio Current (Beardsley et al., 1985; Fang et al., 1991). The Changjiang River contributes $82 \%\left(924 \mathrm{~km}^{3} \mathrm{yr}^{-1}\right.$ fresh water and $4.86 \times 108 \mathrm{tyr}^{-1}$ solid) of the total discharge to the ECS (Tian et al., 1993).

The two study sites with differing land use practices in the Changjiang River estuary and its adjacent ECS were chosen for detailed assessment of their eutrophication histories. Both sites are located in the Zhejiang coastal area, which is the most developed area in China since the 1980s and has been as an area of reported eutrophication where frequent red tides occur (Fig. 1). Site ZC13 $\left(29^{\circ} 6^{\prime} 38^{\prime \prime} \mathrm{N}, 122^{\circ} 16^{\prime} 30^{\prime \prime} \mathrm{E}\right)$ is located in the Taizhou Sea area, a middle coastal area of Zhejiang province in the ECS. The major input on the Taizhou Sea area was the discharge of sewage waste 20 water affected by agriculture and fishery from the coastal areas. Site ZA3 $\left(29^{\circ} 31^{\prime} \mathrm{N}\right.$, $122^{\circ} 36^{\prime} 48^{\prime \prime} E$ ) is located in the north coastal area of Zhejiang province, close to the Zhoushan archipelago. The Zhoushan fishing ground, which is one of the largest fishing ground in the world, are located in the outer part of this area. The site has been receiving discharges of waste water from the coastal developed cities such as Hangzhou, 25 Shanghai, Suzhou and caused serious organic pollution since the 1980s (Liu et al., 1991).
BGD

$9,6261-6291,2012$

Historical records of eutrophication

F. Cheng et al.

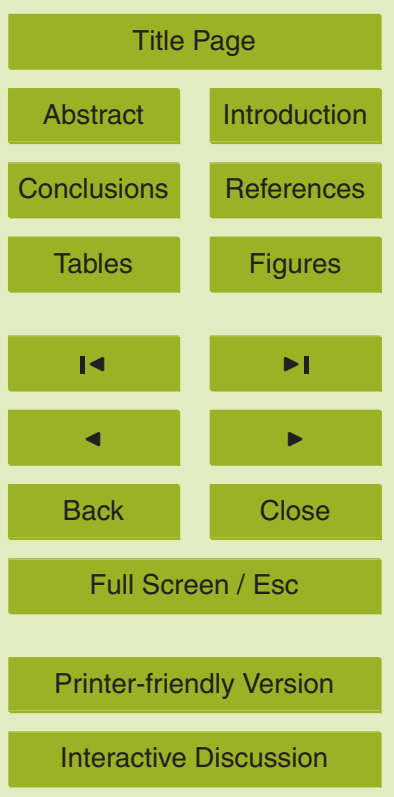




\subsection{Samples collection}

Two cores were collected using gravity corers during two R/V Ecology and Oceanography of Harmful Algal Blooms in China cruises in 2010. Core ZC13 (48 cm length) was collected at a water depth of $25 \mathrm{~m}$ on 24 April 2010 . Core ZA3 (140 cm length), was 5 collected at $49 \mathrm{~m}$ depth on 7 October 2010.

Cores were sectioned into $1 \mathrm{~cm}$ intervals within $24 \mathrm{~h}$ of core collection, stored frozen at $-20^{\circ} \mathrm{C}$ and then freeze-dried. Sediment samples were placed into precleaned PET jars for radionuclides, total organic carbon and nitrogen, biogenic silicon and diatom analysis.

\subsection{Dating}

Both cores were dated at the Qingdao Institute of Marine Geology. Core ZC13 was analyzed for ${ }^{210} \mathrm{~Pb},{ }^{226} \mathrm{Ra}$ and ${ }^{137} \mathrm{Cs}$ using a HPGe gamma spectrometer, following the technical procedures of Appleby et al. (1986). The constant rate of supply (CRS) model was used for calculating chronologies. Core ZA3 was analyzed for ${ }^{210} \mathrm{~Pb}$ radiometric 15 dating technical using multi-channel alpha spectrometer. The CRS and the constant initial concentration (CIC) model was adopted for calculating chronologies (Appleby and Oldfield, 1978; Appleby et al., 1986).

\subsection{Geochemistry}

After removal of carbonate with $10 \% \mathrm{HCl}$ for $12 \mathrm{~h}$, approximately $20 \mathrm{mg}$ sediment samples were dried at $60^{\circ} \mathrm{C}$ and carefully crimp-sealed in tin cans. The total organic carbon (TOC) and total nitrogen (TN) contents of sediments were analyzed on a Flash EA1112 elemental analyzer in Yantai Institute of Coastal Zone Research, China Academy of Science. The precision was $<1 \%$ by repeated analyses of samples.

BSi was analyzed using a combined wet-chemical method (Demaster, 1981; Mort25 lock and Froelich, 1989). About $100 \mathrm{mg}$ of sediment samples were treated with $\mathrm{H}_{2} \mathrm{O}_{2}$

\section{Historical records of eutrophication}

F. Cheng et al.

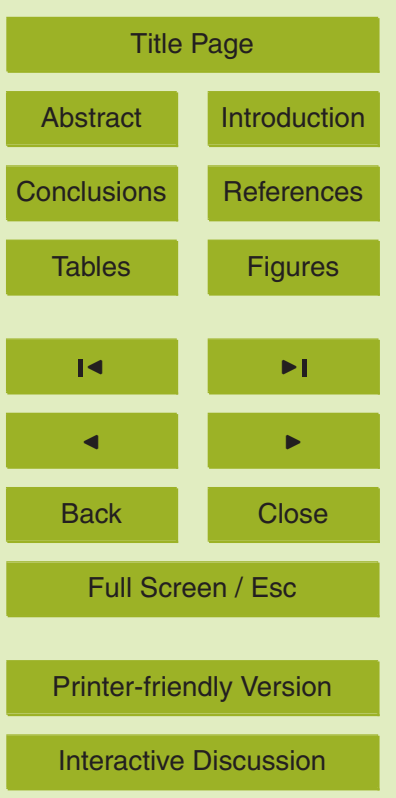


and $10 \% \mathrm{HCl}$ for $3 \mathrm{~h}$, respectively, for removal of organic matter and carbonate. Forty $\mathrm{ml} \mathrm{Na} \mathrm{CO}_{3}\left(2 \mathrm{moll}^{-1}\right)$ solution was added to the samples which had pre-treatment in the $100 \mathrm{ml}$ tube, mixed well and digested at $85^{\circ} \mathrm{C}$ in a water-bath with lid for $5 \mathrm{~h}$ to extract the BSi. Subsamples were taken at each hour and analysed using the molybdate 5 blue spectrophotometric method to measure BSi. The amount of BSi is calculated by the intercept of the line through the time course aliquots. The precision of this extraction procedure was $<5 \%$.

\subsection{Diatoms}

The diatom extraction followed the technique of Battarbee (1986), Ronnberg and Bons10 dorff (2004). Subsamples of sediments were treated with $10 \% \mathrm{HCl}$ and $30 \% \mathrm{H}_{2} \mathrm{O}_{2}$ for $3 \mathrm{~h}$ to remove the carbonate and organic matter and then weighed. The samples were then gently added with a specific gravity fluid (density 2.45 ), containing zinc bromide to separate the diatoms. Typically $200 \mu \mathrm{l}$ were taken from suspension and dried onto cover-slips at $85^{\circ} \mathrm{C}$ on an electric hot plate. Naphrax ${ }^{\mathrm{TM}}$ was used to mount the 5 slides permanently. Diatoms were analyzed at $\times 1000$ magnification with an Olympus $\mathrm{BH}-2$ light microscope with differential interference contrast. A minimum of 300 diatom valves (Scherader and Gersonde, 1978) was counted in each sample. Diatom taxonomy follows Guo and Qian (2003); Hasle and Syvertsen (1996); Lan et al. (1995), nomenclature and ecological information refered to as follows (Hasle and Syvertsen, 20 1996; Guo and Qian, 2003; Lan et al., 1995; Qi, 2003; Stoermer and Smol, 1999; Zhu et al., 1995).

\subsection{Data analysis}

A multivariate ordination technique was applied to the diatom analysis to describe and classify the sample-species relationship in the sediment cores. Detrended correspondence analysis (DCA) of the diatom assemblages was used on a combined diatom species help group similar samples together based on species composition in percent

\section{BGD}

$9,6261-6291,2012$

\section{Historical records of eutrophication}

F. Cheng et al.

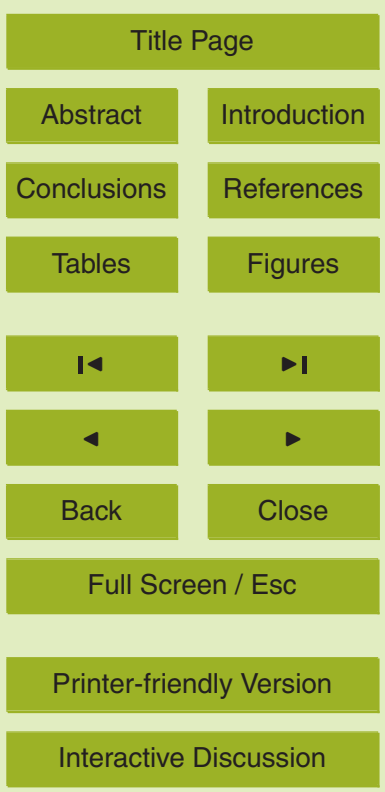

Interactive Discussion 
abundance of species. It is an indirect gradient analysis that classifies the distribution mode of diatom assemblages due to the length assessment of samples and species in the first axes (Terbraak and Verdonschot, 1995). The cluster analysis was performed using the CANOCO 4.52 program. The absolute abundance $\left(N_{\mathrm{a}}\right)$ was estimated by the 5 equation:

$N_{\mathrm{a}}=[n A V / a v W]$

Here $n$ is the total number of diatom valves counted, $A$ is an area of cover-slip $\left(\mathrm{mm}^{2}\right)$, $V$ is total volume of the suspension which is diatom extraction in a sample $(\mathrm{ml}), a$ is the 10 area of one field of view $\left(\mathrm{mm}^{2}\right), v$ is the volume of suspension which taken onto the cover-slip $(\mathrm{ml})$, and $W$ is the dry weight of the sample $(\mathrm{g})$. The relative abundance of diatom valves $\left(N_{\mathrm{r}}\right)$ is the percentage of each species in a sample due to the $N_{\mathrm{a}}$.

The diatom community diversity $\left(H^{\prime}\right)$ was calculated using the equations as follows:

$H^{\prime}=\sum_{i=1}^{S} P i \times \log _{2} P i \quad$ (Shannon and Weaver, 1949)

Here $P i$ is relative abundance of diatom $\left(N_{r}\right), S$ is a total number of species (species richness).

\section{Results}

\subsection{Core ZC13}

20 The core which was inspected indicated black sediment composed of clays and silts and no evidences (e.g., burrows or fragments of animals) of major biological or physical disturbance of the sediments.

Excess ${ }^{210} \mathrm{~Pb}$ activity was measured in the sediments of core ZC13 from the surface to $48 \mathrm{~cm}$ true depth (Fig. 2a), identified as equivalent to $60 \mathrm{yr}$ sediment accumulation.

\section{BGD}

$9,6261-6291,2012$

\section{Historical records of eutrophication}

F. Cheng et al.

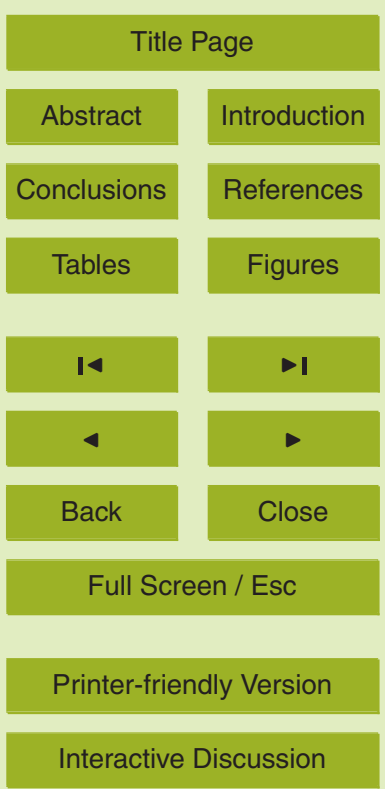

Interactive Discussion 
The strong linear relationship between excess ${ }^{210} \mathrm{~Pb}$ activity and depth were plotted on a logarithmic scale $\left(r^{2}=0.963 ; p<0.001\right)$, and the sedimentation rate was estimated at ca. $0.89 \mathrm{~cm} \mathrm{yr}^{-1}$. The ${ }^{137} \mathrm{Cs}$ activity had a relatively well-resolved peak at $20 \mathrm{~cm}$ almost certainly recorded as the fallout mainly from the 1986 Chernobyl accident. The 5 sub-surface peak was a record of the 1963 fallout from maximum from nuclear weapons testing, which had presumably been masked by downward diffusion (Fig. 2). The sedimentation rate estimated with ${ }^{137} \mathrm{Cs}$ was ca. $0.87 \mathrm{~cm} \mathrm{yr}^{-1}$ which was in accordance with the ${ }^{210} \mathrm{~Pb}$-derived rate.

Total percent organic carbon (TOC), total percent nitrogen (TN) and biogenic silica 10 (BSi) all showed an increase upward the top of core ZC13 (Fig. 3a). Profiles of TOC, TN and BSi content showed the similar trends that most marked increase began from $40 \mathrm{~cm}$ (1971) and had a distinct decrease between 15-10 cm (ca. 1995-1998). All three proxies had the major peak at the top. The contents of TOC, TN and BSi from the core ranged from $0.282 \%$ to $0.793 \%$ (average $0.650 \%$ ), $0.032 \%$ to $0.093 \%$ (average $0.077 \%$ ) and $0.468 \%$ to $1.174 \%$ (average $0.841 \%$ ), respectively.

A total of 56 diatom species were identified in core ZC13. However, some species were rare and occurred only occasional, hence 14 species which occurred in percentages over $5 \%$ were considered common to be used in data analysis. A cluster analysis showed two distinct breaks identified at $15 \mathrm{~cm}$ and $40 \mathrm{~cm}$ based upon both the cell abundance and diatoms composition, producing three zones in the core ZC13. The results of diatom cell abundance $\left(N_{\mathrm{a}}\right)$ showed an increase trend in the core (Fig. 4a). Zone 1, from $48 \mathrm{~cm}$ to $40 \mathrm{~cm}$ (ca. 1955-1972), had low values of diatom cell abundance. Total $N_{\mathrm{a}}$ ranged from 5 to 21 valves $^{-1}$, with an average of 12 valves $^{-1}$. Zone 2 , from $40 \mathrm{~cm}$ to $15 \mathrm{~cm}$ (ca. 1973-1995), showed a sudden rising trend from $25 \mathrm{~cm}$ (ca. 25 1985). The total number of $N_{\mathrm{a}}$ ranged from 94 to 104 valves $^{-1}$ with an average of 99 valves $^{-1}$. Zone 3 , from $15 \mathrm{~cm}$ to surface (ca. 1996-2009), showed fluctuations in diatom cell abundance. The total number of $N_{\mathrm{a}}$ gave the highest value for the whole core, ranging from 167 to 304 valves $^{-1}$ with an average of 223 valves $^{-1}$.
BGD

$9,6261-6291,2012$

\section{Historical records of eutrophication}

F. Cheng et al.

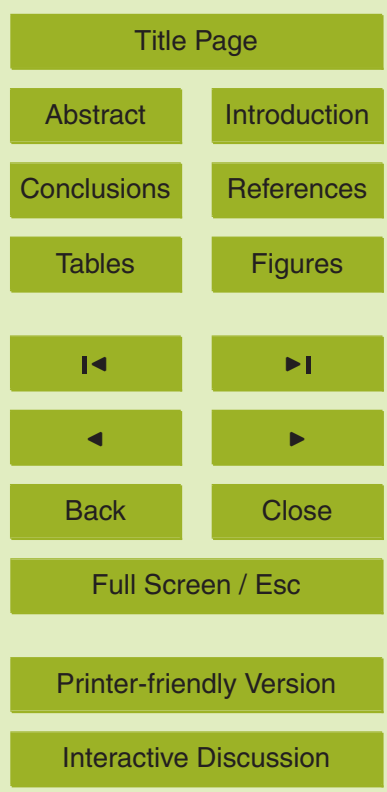

Interactive Discussion 
The increase of diatom cell abundance is associated with changes in composition of diatom assemblages. Only the species Podosira stelliger $(\sim 68 \%)$ and Cyclotella striata $(\sim 13 \%)$ were enriched in Zone 1 . Wang et al. (2001) reported that $P$. stelliger and the Cyclotella genus, were enriched as major species in poor diatom-preserved with only the central part of the frustule preserved. A remarkable shift in dominance occurred at the transition from Zone 1 into Zone 2. The species $P$. stelliger decreased sharply in relative abundance $\left(N_{\mathrm{r}}\right)$ to $9 \%$ in Zone 2 and the genus of Cyclotella stayed dominant. Two species of genus of Actinocyclus, $A$. disseminatus $(\sim 13 \%)$ and $A$.

ehrenbergi $(\sim 9 \%)$, which prefer eutrophic habitats and were identified as red tide species in coastal waters of China (Qi, 2003) increased to be the dominated species in Zone 3 (Fig. 5).

The species richness $(S)$ of diatom assemblages in Zone 1 was the lowest for the whole core. There is a major peak at $15 \mathrm{~cm}$ (ca. 1995) following a dramatic rise from $40 \mathrm{~cm}$ (ca. 1972). The index showed a marked decline at $10 \mathrm{~cm}$ (ca. 1998) and then gradually increased to the top. The Shannon-Weaver index $\left(H^{\prime}\right)$ showed a similar tendency in value changes, yet it had a fluctuating decline from $15 \mathrm{~cm}$ to the top. The profiles of $N_{\mathrm{a}}$ in planktonic diatoms ranged from 4 to 208 and showed an increasing trend up the core (Fig. 4a). Planktonic diatoms dominated core ZC13 indicating that the deposited diatoms frustules in sediments were mainly from diatoms living in water column.

\subsection{Core ZA3}

Some biological shell debris was found in the $120-140 \mathrm{~cm}$ layer at the bottom of the core, indicating that the bottom of the core suffered from episodes of sediment resuspension or small-scale $(<1 \mathrm{~cm})$ vertical mixing (bioturbation). Therefore, we selected the upper $115 \mathrm{~cm}$ of sediment for dating and paleoecological analyses.

Excess ${ }^{210} \mathrm{~Pb}$ activity was measured in the sediments of core ZA3 from the surface to $115 \mathrm{~cm}$ true depth (Fig. 2b), calculated as corresponding to ca. $140 \mathrm{yr}$ accumulation.

\section{BGD}

$9,6261-6291,2012$

\section{Historical records of eutrophication}

F. Cheng et al.

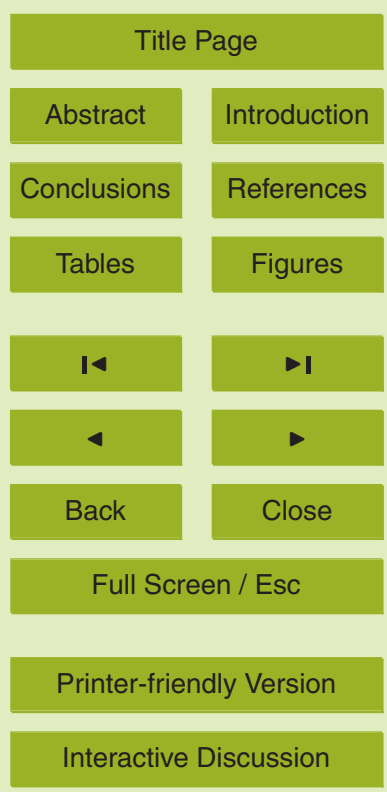

Interactive Discussion 
Based on the CRS and CIC model two distinct changes in sedimentation rate were calculated. From $25 \mathrm{~cm}$ to $75 \mathrm{~cm}$ the sedimentation rate was ca. $1.78 \mathrm{~cm} \mathrm{yr}^{-1}$. The upper $25 \mathrm{~cm}$ revealed an average sedimentation rate of ca. $0.71 \mathrm{~cm} \mathrm{yr}^{-1}$.

The profiles of TOC, TN and BSi in core ZA3 all showed slightly increasing but vari5 able trends toward the top from ca. $20 \mathrm{~cm}$ (Fig. 3b). BSi began to increase slowly at $35 \mathrm{~cm}$ (ca. 1975) with a peak at $10 \mathrm{~cm}$ (ca. 1998), while the major peaks of TOC and TN are at the top and both have a marked increasing tendency from $20 \mathrm{~cm}$ (ca. 1985). The contents of TOC, TN and BSi are in the range of $0.369 \%$ to $0.620 \%$ (average $0.539 \%$ ), $0.032 \%$ to $0.075 \%$ (average $0.066 \%$ ) and $0.746 \%$ to $0.801 \%$ (average $0.773 \%$ ), re10 spectively.

We selected the upper $100 \mathrm{~cm}$ for diatom analysis in core ZA3 because of the bioturbation recognized in chronology. Altogether, 46 diatom species were identified, of which only 13 species which occurred in percentages $>5 \%$ as common species for data analysis. While a distinct break was identified at $12 \mathrm{~cm}$ based on species composition in percent abundance of the core was split into two zones (Fig. 4b). Zone 1, from 95 to $45 \mathrm{~cm}$ (ca. 1932-1971), where the changes of abundance were minimal as the total number of $N_{\mathrm{a}}$ ranged from 234 to 335 valves $\mathrm{g}^{-1}$ ( 284 valves $^{-1}$ in average). Zone 2 , from $45 \mathrm{~cm}$ to surface (ca. 1972-2010), showed a clear change around 15-20 cm (ca. 1985-1993) to high values in $N_{\mathrm{a}}$, and the average $N_{\mathrm{a}}$ was 456 valves ${ }^{-1}$ (ranged 20 from 242 to 812 valves $\mathrm{g}^{-1}$ ). The diatom cell abundance showed a rising trend and had a maximum at $5 \mathrm{~cm}$ (ca. 2005) in Zone 2 (Fig. 4b).

The diatom composition in core ZA3 was different from core ZC13, indicating an environmental heterogeneity in the ECS. The species Coscinodiscus argus ( $30 \%)$, C. stylorum $(\sim 20 \%)$ and C. striata $(\sim 13 \%)$ dominated Zone 1 and were abundant throughout the core. These species are common species deposited well in sediments in the ECS (Wang et al., 2001, 2003; Lan et al., 1995). The red tide species $C$. radiatus ( $\sim 13 \%)$ increased in abundance at the transition from Zone 1 to Zone 2 to become dominant. Simultaneously, we found increased trends in other red tide species, such as Paralia sulcata and Coscinodiscus subtilis. It was noticed that Chaetoceros sp. ( 10\%)

\section{BGD}

$9,6261-6291,2012$

\section{Historical records of eutrophication}

F. Cheng et al.

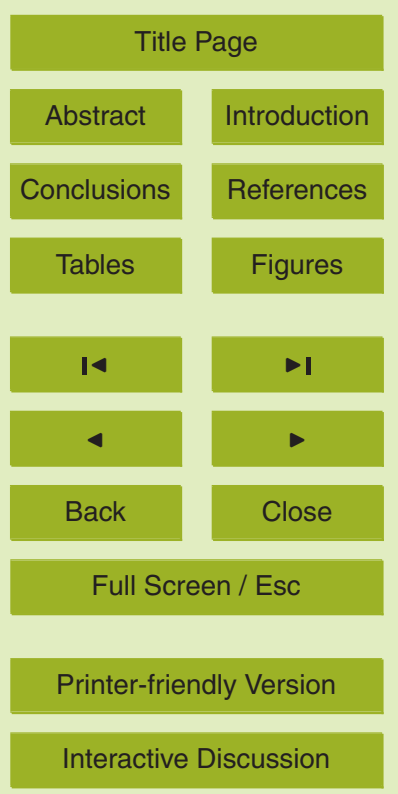

Interactive Discussion 
dominated the surface sediments while other diatoms decreased to lower than $5 \%$, indicating that blooms of Chaetoceros may occur in this location (Fig. 6).

The indexes of $S$ and $H^{\prime}$ showed similar trends in value changes. There were some fluctuations in the core, but the most marked change occured at ca. $15-20 \mathrm{~cm}$. The 5 major peaks of those indexes were all at the top of Zone 2. The $N_{a}$ of planktonic diatoms showed an increasing trend in the core and had a major peak at $5 \mathrm{~cm}$ (ca. 2005). The profiles of $N_{\mathrm{a}}$ in planktonic diatoms ranged from 190 to 599 valves $\mathrm{g}^{-1}$ with an average of 309 valves $\mathrm{g}^{-1}$ (Fig. 4b).

\section{Discussion}

10 This study demonstrated that a multiproxy paleoecological approach was effective in studying the Changjiang (Yangtze) River and its adjacent ECS. The results of this study provided useful data for reconstructing eutrophication histories of two locations in the ECS. Detectable changes occurring with the intensification of anthropogenic activities in the 20th century were observed through the chronology and interpretation of the historical records.

\subsection{Eutrophication histories reconstructed by paleoecological methods}

Studies of sedimentary records usually link increased TOC to increased phytoplankton production (Andren, 1999; Pinturier-Geiss et al., 2002; Zimmerman and Canuel, 2000), supporting the diatom interpretations (discussed below). In the core ZC13, the trends in profiles of TOC, TN showed relative low and rather stable contents before the 1970s, suggesting a low and stable primary production in the water column compared to recent years. There were fluctuations of the three proxies from the 1980s to the present, but with a rising trend overall, indicating a marked increase in primary production during this period in the ECS which coincided with the rapid development of the economy in southeast coastal areas of China since the 1980s. BSi is predominantly composed of

BGD

$9,6261-6291,2012$

Historical records of eutrophication

F. Cheng et al.

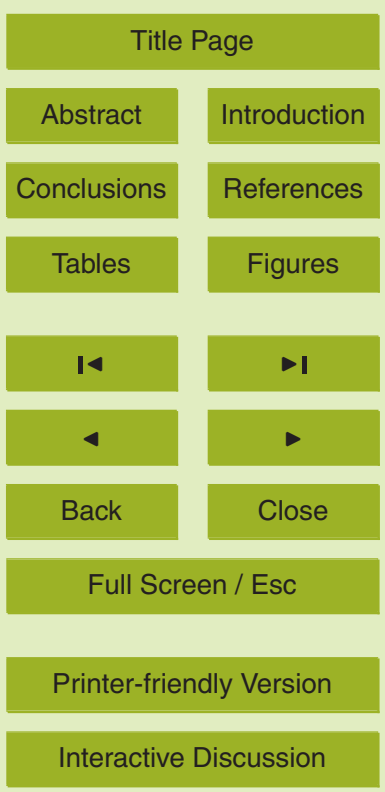


diatom frustules and can be used as an indication of diatom production. It also gives an indication of silica limitation in early 1990 s after prolonged large diatom blooms which have occurred during the mid-1980s, as these deplete silica from the water column. So there first is an observable increase of BSi in sediments since 1970, followed by

5 a decrease in the early 1990s and silica has become limiting for diatoms to grow and caused marked drop interrupting overall increasing trends in all geochemical proxies in the 1990s. After 2000, TOC, TN and BSi all had increased and mostly reached a peak at the top of the core, indicating the intensification of eutrophication in recent years, leading to an increased frequency of red tides in this area (Zhou et al., 2008).

10 Increases in diatom cell abundances are often an early sign of eutrophication (Smith, 2003). Low diatom abundance before 1970 indicated poor preservation and relative low level nutrient in the Taizhou Sea area. The profiles of diatom abundance showed a rapid increase in nutrient concentration from ca. 1973 to 1995, which coincided with the increased use of chemical fertilizers in China, especially in the southeast coastal areas in

the 1970s (Duan et al., 2008). There was a sudden rise in diatom abundance between the mid-1980s and the mid-1990s, indicating that eutrophication may have expanded in this period in the ECS. These results agree well with Bao et al. (2006), who reported that there was a 1.6-fold increase in nitrogen output caused by human activities to the Changjiang River from the 1980s to the 1990s leading to serious eutrophication.

20 There was a decline in diatom abundance between the mid-1990s and early 2000s and the findings are in agreement with those provided by BSi. Growing phytoplankton and benthic microalgae production caused by higher nutrient loadings to the coast have always resulted in red tides (Chen, 2008; Gao and Song, 2005; Li et al., 2007). In the Changjiang River estuary and its adjacent ECS, there were rarely reports of red 25 tides until 1972, but the occurrence of red tides has dramatically increased since 1980 (Wang, 2006).

Evidence from earlier studies suggested that eutrophication would not only enhance the primary production but also cause changes in phytoplankton composition, especially shifts in dominant species (Lefebvre et al., 2011; Olli et al., 2011; Marshall et al.,

\section{BGD}

9, 6261-6291, 2012

\section{Historical records of eutrophication}

F. Cheng et al.

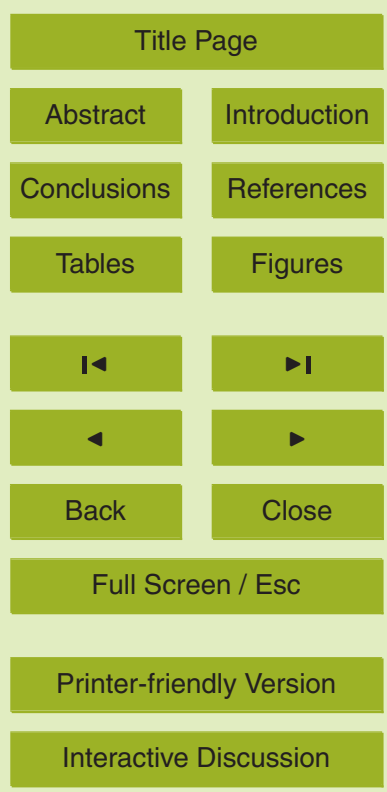


2003). One notable phenomenon was the change of the cell abundance of the dominant species $P$. stelliger in the ECS especially in the water column of $40-50 \mathrm{~m}$ (Wang et al., 2003, 2001). There was a sharp decrease in its relative abundance since the mid-1970s, coinciding with an increase of diatom biomass and species richness in this 5 time. The time of the shift to eutrophic conditions appeared to be linked with the increase of eutrophic diatoms. Paralia sulcata, an indicative species of high dissolved nitrogen loaded waters (McQuoid and Nordberg, 2003) has increased since the 1970s. The species $A$. disseminates and $A$. ehrenbergi, have increased and become the dominant species since ca. 1990. This may indicate higher nutrient loadings in this period 10 due to more wastewater discharge and urbanization from economic development along the Zhejiang coastline (Chen, 2008).

The species richness $(S)$ and the diversity $\left(H^{\prime}\right)$ of diatom assemblages have increased since the mid-1970 regularly during the period of increased diatom cell abundance. These two indexes showed a decrease since the mid-1990s, which was the period of expansion of eutrophication in the ECS. The amplitude in fluctuations of species richness and diversity seems an indicator of a stressed environment since the mid1990s. Evidence of the shift to eutrophication in the Taizhou Sea area was found in the increase of planktonic diatoms. Similar changes in planktonic diatoms associated with eutrophication have been reported from the Baltic Sea (Andrén, 1999), Roskild Fjord 20 (Clarke et al., 2003) and Laajalahti Bay (Kauppila et al., 2005).

The concentrations of TOC, TN and BSi in core ZA3 were relatively stable before the mid-1980s, indicating seldom disturbance in the water column of the Zhoushan Sea area. Profiles of the three proxies showed a rising trend with fluctuations since the mid-1980s, indicating increasing nutrient loads and more anthropogenic influence on the ECS during this period. Similarly, an increase of dissolved nitrogen (DIN) in the Changjiang River estuary and its adjacent ECS also occurred in the 1980s (Wang, 2006).

The profiles of diatom cell abundance gave a similar eutrophication history in the Zhoushan Sea area. High diatom cell abundance was found in the core ZA3 because
BGD

$9,6261-6291,2012$

\section{Historical records of eutrophication}

F. Cheng et al.

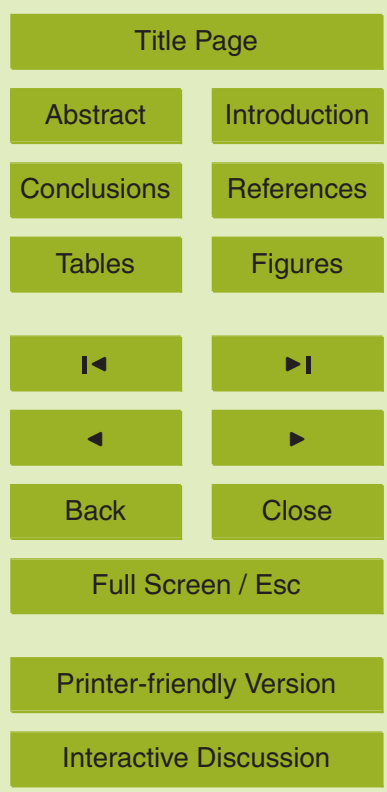

6274 
its environmental characteristics support phytoplankton growth. A relatively low and stable level primary production in the water column before the mid-1970s was clearly shown by the diatom cell abundance profiles. The initial increase of diatom cell abundance in the 1980s is in accordance with the rapid increase of the Zhejiang coastline 5 economy. Increasing discharge of sewage wastewater from coastal developed cities and consumption of fertilizer are the major reasons of the effect on the Zhoushan Sea area. The period of greatest effect between the mid-1990s and 2000s indicated by two profiles was confirmed by more red tides occurring here (Wang, 2006). Meanwhile, phytoplankton production enhancement due to eutrophication caused hypoxia in 10 bottom water and contributed to reduction of the production in the Zhoushan fishing ground.

Composition of diatom assemblages in the Zhoushan Sea area also indicated several changes in water quality over the last century (based on the sediment records). The relative abundance of the common species Coscinodiscus argus declined sharply since the 1970s while $C$. radiatus, which is identified as red tide species in coastal waters of China (Qi, 2003) became abundant. Similarly to the interpretation of the core $\mathrm{ZC13}$, the results indicated that the phytoplankton assemblages were greatly influenced by eutrophication in the ECS. Notably, Chaetoceros dominated in surface sediments. This phenomenon coincides with reports that more frequent red tides of Chaetoceros have occurred in the Zhoushan Sea area in recent years (State-OceanAdministration, 2009). Though vegetative cells of Chaetoceros preserve poorly in the sediments, the existed frustules of Chaetoceros of the top of the core ZC13 may be preserved only for very short time in the sediments and we could examine them timely since the blooms just occurred.

The diatom assemblage showed fluctuations in species richness and diversity during the period of maximum eutrophication, a sign of an unbalanced environment condition. The species richness and diversity showed increasing trends, which were attributed to increased red tide species. Profiles of planktonic diatoms not only showed an increasing trend but also dominated the whole core, indicating high-nutrient coastal waters
BGD

9, 6261-6291, 2012

\section{Historical records of eutrophication}

F. Cheng et al.

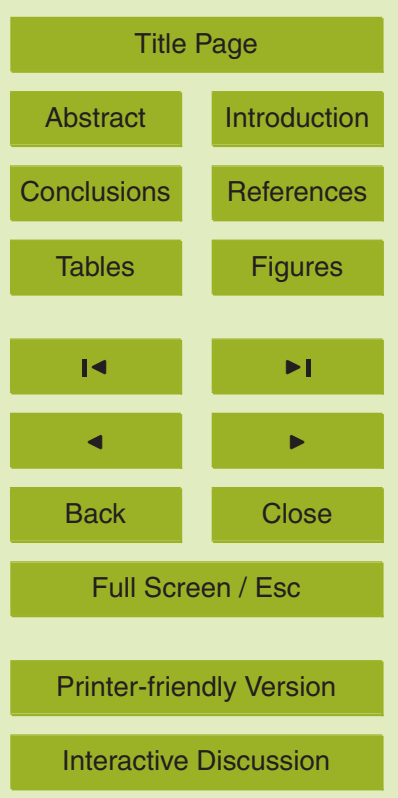

Interactive Discussion 
in the Zhoushan Sea area, and that the eutrophication has become more and more serious in the coastal waters.

The diatom record did not include all species of phytoplankton in the ECS. Large blooms of Skeletonema costatum have occurred frequently in the ECS (Zhou et al., 5 2008), but this delicate and lightly silicified diatom does not preserve well in the sediments (Clarke et al., 2006). The poor preservation of this species has been linked with silica limitation after diatom blooms (Parsons et al., 2002).

\subsection{Histories of phytoplankton affected by eutrophication in Changjiang River estuary and its adjacent ECS}

10 Long-term changes of the phytoplankton community from a location close to our sites support our interpretations of paleoecological data. These data suggested that phytoplankton assemblages could have been greatly influenced by the eutrophication in the ECS in the last $30 \mathrm{yr}$ (Fig. 7). Phytoplankton production indicated by $\mathrm{Chl}$ a has increased in the Changjiang River estuary and its adjacent ECS in the summer during the last 30 yr: 1980 to 2000 (Wang et al., 2009; Zhou et al., 2003; Shen et al., 1995; Ning et al., 1986; Liu et al., 2001) (locations see Table 1) (Fig. 7). Another response is the species diversity $\left(H^{\prime}\right)$ of phytoplankton communities to the changing environment. The profiles of $H^{\prime}$ increased to a maximum in 2001 and then fluctuated, which corresponded with our results ( $\mathrm{Li}, 2008)$. As these results showed, the fluctuation of species richness $(S)$ and diversity $\left(H^{\prime}\right)$ can partially indicate the uneven species distributions and the increase in red tide species. Changes in biomass and composition of the phytoplankton community would be detrimental to the health of the coastal ecosystem, leading to poor food quality for zooplankton and fish populations (Parsons et al., 2006). Thus, the production of Zhoushan fishing ground has decreased dramaticlly in recent

BGD

$9,6261-6291,2012$

Historical records of eutrophication

F. Cheng et al.

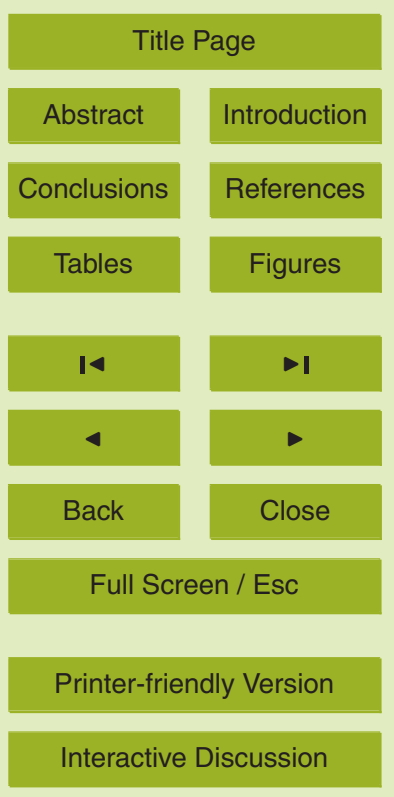




\subsection{Anthropogenic influences and ongoing study of eutrophication in the Changjiang River and its adjacent ECS}

The increases of industrialization, urbanization and anthropogenic discharges have altered the nature and nutrient loadings of the Changjiang River estuary and its adjacent

5 ECS. It is the most developed economic area in China and has suffered from numerous alternations. The Three Gorges Dam is expected to constrain flooding and generate electricity to meet the growing needs of the rapidly growing population in China, especially the ECS coastal area (Li et al., 2007). But in a long run, however, a decreasing trend in silicate might occur after construction of the Three Gorges Dam. The South to 10 North water conservancy project in China will remove about 48 billion t of water each year from the Changjiang River by the year 2050 to reduce flooding in the south and droughts in the north (Jiao et al., 2007). These past and future alterations will further change the nutrient ratios, sediment composition, as well as the biogeochemical cycling of this area. Continuing eutrophication linked with anthropogenic activities should be considered the most serious and challenging environmental problem for a long time.

Using paleoecological proxies, we have shown the history of eutrophication of two sites in the Changjiang River estuary and its adjacent ECS. Both sites were not eutrophic in the past and have been under eutrophic conditions since the 1970s, linked with anthropogenic activities. The eutrophication has accelerated since the 1990s and increased nutrients inputs into the ECS were supported by paleoecological results. Economic development along the coastline of the ECS appears to be the most responsible for the development of eutrophication due to increased fertilizer use and enhanced discharge of sewage waste waters. Consequently, this has dramaticlly increased the phytoplankton production and led to more red tides in the ECS.

\section{BGD}

$9,6261-6291,2012$

Historical records of eutrophication

F. Cheng et al.

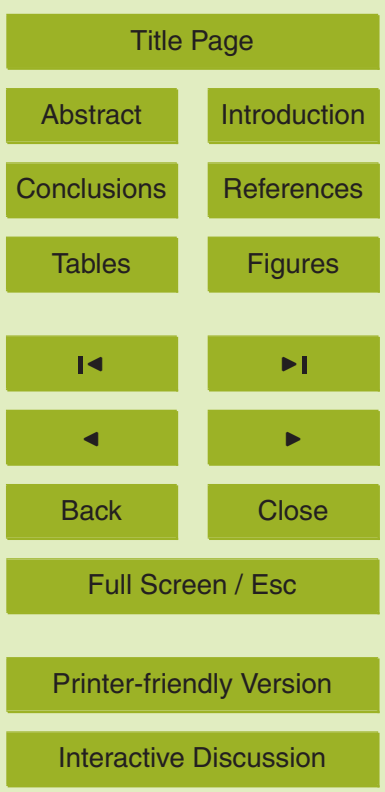


Acknowledgements. We greatly thank Prof. J. Morrison (University of Wollongong) for language modification, Dr. Yunfeng Wang and Fanzhou Kong for sediment cores collection, and Dr. Baoping Di for taxonomic assistance. This work was funded by the National Basic Research Program of China (2010CB428706), National Natural Science Foundation of China for Creative

5 Research Groups (41121064), and Knowledge Innovation Program of the Chinese Academy of Sciences (KZCX2-YW-Q07-02).

\section{References}

Anderson, N. J. and Vos, P.: Learning from the past: diatoms as palaeoecological indicators of changes in marine environments, Neth. J. Aquat. Ecol., 26, 19-30, 1992.

Andrén, E.: Changes in the composition of the diatom flora during the last century indicate increased eutrophication of the Oder estuary, South-western Baltic Sea, Estuar. Coast. Shelf S., 48, 665-676, 1999.

Appleby, P. G. and Oldfield, F.: The calculation of lead-210 dates assuming a constant rate of supply of unsupported ${ }^{210} \mathrm{~Pb}$ to the sediment, Catena, 5, 1-8, 1978.

15 Appleby, P. G., Nolan, P. J., Gifford, D. W., Godfrey, M. J., Oldfield, F., Anderson, N. J., and Battarbee, R. W.: ${ }^{210} \mathrm{~Pb}$ dating by low background gamma counting, Hydrobiologia, 143, 2127, 1986.

Bao, X., Watanabe, M., Wang, Q. X., Hayashi, S., and Liu, J. Y.: Nitrogen budgets of agricultural fields of the Changjiang River basin from 1980 to 1990, Sci. Total Environ., 363, 136-148,

202006.

Battarbee, R. W.: Diatom analysis, in: Handbook of Holocene Palaeoecology and Palaeohydrology, edited by: Berglund, B. E., Wiley, Chichester, 527-570, 1986.

Beardsley, R. C., Limeburner, R., Yu, H., and Cannon, G. A.: Discharge of the Changjiang (Yangtze River) into the East China Sea, Cont. Shelf Res., 4, 57-76, 1985.

Billen, G. and Garnier, J.: The Phison River plume: coastal eutrophication in response to changes in land use and water management in the watershed, Aquat. Microb. Ecol., 13, 3-17, 1997.

Boesch, D. F.: Challenges and opportunities for science in reducing nutrient over-enrichment of coastal ecosystems, Estuaries, 25, 886-900, 2002.

BGD

$9,6261-6291,2012$

\section{Historical records of eutrophication}

F. Cheng et al.

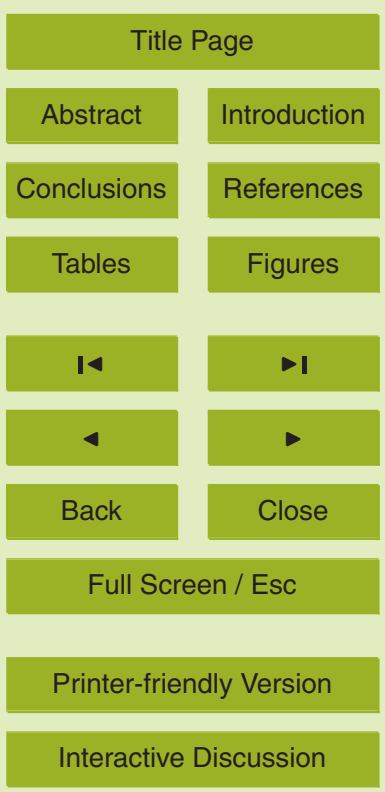


Charles, D. F., Smol, J. P., and Engstrom, D. R.: Paleolimnological approaches to biological monitoring, in: Biological Monitoring of Aquatic Systems, edited by: Loeb, S. L. and Spacie, A., Lewis Publishers, Boca Raton, FL, 233-293, 1994.

Chen, C. T. A.: Distributions of nutrients in the East China Sea and the South China Sea connection, J. Oceanogr., 64, 737-751, 2008.

Chen, Y. L. L., Chen, H. Y., Gong, G. C., Lin, Y. H., Jan, S., and Takahashi, M.: Phytoplankton production during a summer coastal upwelling in the East China Sea, Cont. Shelf Res., 24, 1321-1338, 2004.

Clarke, A. L., Juggins, S., and Conley, D.: A 150-year reconstruction of the history of coastal eutrophication in Roskilde Fjord, Denmark, Mar. Pollut. Bull., 46, 1615-1618, 2003.

Clarke, A. L., Weckstrom, K., Conley, D. J., Anderson, N. J., Adser, F., Andren, E., de Jonge, V. N., Ellegaard, M., Juggins, S., Kauppila, P., Korhola, A., Reuss, N., Telford, R. J., and Vaalgamaa, S.: Long-term trends in eutrophication and nutrients in the coastal zone, Limnol. Oceanogr., 51, 385-397, 2006.

Cloern, J. E.: Our evolving conceptual model of the coastal eutrophication problem, Mar. Ecol.Prog. Ser., 210, 223-253, 2001.

Conley, D. J., Markager, S., Andersen, J., Ellermann, T., and Svendsen, L. M.: Coastal eutrophication and the Danish National Aquatic Monitoring and Assessment Program, Estuaries, 25, 848-861, 2002.

20 Cooper, S. R. and Brush, G. S.: A 2,500-year history of anoxia and eutrophication in Chesapeake Bay, Estuaries, 16, 617-626, 1993.

Cornwell, J. C., Conley, D. J., Owens, M., and Stevenson, J. C.: A sediment chronology of the eutrophication of Chesapeake Bay, Estuaries, 19, 488-499, 1996.

De Vernal, A., Rochon, A., and Radi, T.: Paleoceanography, biological proxies: dinoflagellates, in: Encyclopedia of Quaternary Science, edited by: Scott, A. E., Elsevier, Oxford, 1652-1667, 2007.

Demaster, D. J.: The supply and accumulation of silica in the marine environment, Geochim. Cosmochim. Ac., 45, 1715-1732, 1981.

Duan, S., Liang, T., Zhang, S., Wang, L., Zhang, X., and Chen, X.: Seasonal changes in nitrogen and phosphorus transport in the lower Changjiang River before the construction of the Three Gorges Dam, Estuar. Coast. Shelf S., 79, 239-250, 2008.

Elmgren, R., and Larsson, U.: Nitrogen and the Baltic Sea: managing nitrogen in relation to phosphorus, The Scientific World, 1, Suppl 2, 371-377, 2001.
BGD

9, 6261-6291, 2012

\section{Historical records of eutrophication}

F. Cheng et al.

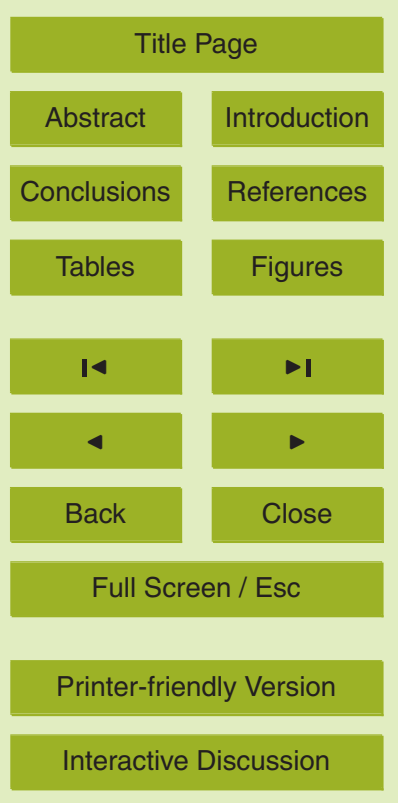


Fang, G. H., Zhao, B. R., and Zhu, Y. H.: Water volume transport through the Taiwan Strait and the continental shelf of the East China Sea measured with current meters, in: Oceanography of Asian Marginal Seas, edited by: Takano, K., Elsevier Oceanography Series, Elsevier, Oxford, 345-358, 1991.

5 Ficken, K. J. and Farrimond, P.: Sedimentary lipid geochemistry of Framvaren - impacts of a changing environment, Mar. Chem., 51, 31-43, 1995.

Gao, X. L. and Song, J. M.: Phytoplankton distributions and their relationship with the environment in the Changjiang Estuary, China, Mar. Pollut. Bull., 50, 327-335, 2005.

Gooday, A. J., Jorissen, F., Levin, L. A., Middelburg, J. J., Naqvi, S. W. A., Rabalais, N. N., Scranton, M., and Zhang, J.: Historical records of coastal eutrophication-induced hypoxia, Biogeosciences, 6, 1707-1745, doi:doi:10.5194/bg-6-1707-2009, 2009.

Guo, Y. and Qian, S.: Bacillariophyta in Flora Alarum marginatum sinistrum, Science Press, Beijing, 2003 (in Chinese).

Hasle, G. R. and Syvertsen, E. E.: Marine diatoms, in: Identifying Marine Diatoms and Dinoflag15 ellates, edited by: Tomas, C. R., Academic Press, San Diego, 5-385, 1996.

Jiao, N., Zhang, Y., Zeng, Y., Gardner, W. D., Mishonov, A. V., Richardson, M. J., Hong, N., Pan, D., Yan, X. H., Jo, Y. H., Chen, C. T., Wang, P., Chen, Y., Hong, H., Bai, Y., Chen, X., Huang, B., Deng, H., Shi, Y., and Yang, D.: Ecological anomalies in the East China Sea: impacts of the Three Gorges Dam?, Water Res., 41, 1287-1293, 2007.

Jonsson, P. and Carman, R.: Changes in deposition of organic matter and nutrients in the Baltic Sea during the twentieth century, Mar. Pollut. Bull., 28, 417-426, 1994.

Jorissen, F. J., Fontanier, C., and Thomas, E.: Paleoceanographical proxies based on deepsea benthic foraminiferal assemblage characteristics, in: Developments in Marine Geology, edited by: Marcel, C. H. and Vernal, A. D., Biological tracers and biomarkers, Elsevier, Oxford, 263-325, 2007.

Kauppila, P., Weckstrom, K., Vaalgamaa, S., Korhola, A., Pitkanen, H., Reuss, N., and Drew, S.: Tracing pollution and recovery using sediments in an urban estuary, Northern Baltic Sea: are we far from ecological reference conditions?, Mar. Ecol.-Prog. Ser., 29, 35-53, 2005.

Lan, D. Z., Cheng, Z. D., and Liu, S. Z.: Diatoms in Late Quaternary Sediments from the South 30 China Sea, Ocean Press, Beijing, 1995.

Lefebvre, A., Guiselin, N., Barbet, F., and Artigas, F. L.: Long-term hydrological and phytoplankton monitoring (1992-2007) of three potentially eutrophic systems in the Eastern English Channel and the Southern Bight of the North Sea, ICES J. Mar. Sci., 68, 2029-2043, 2011.

\section{BGD}

$9,6261-6291,2012$

\section{Historical records of eutrophication}

F. Cheng et al.

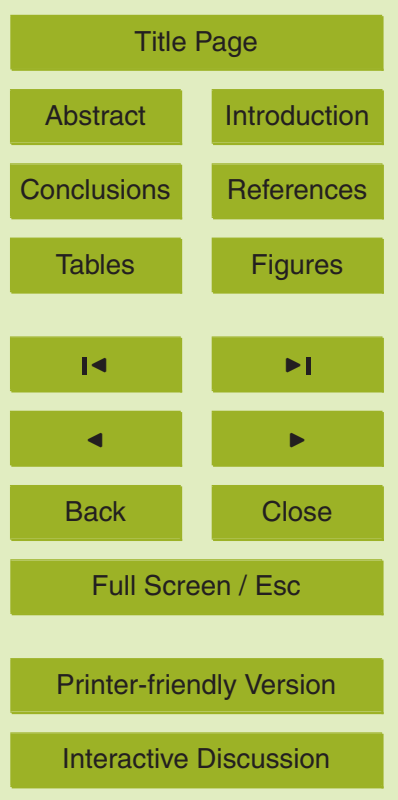


$\mathrm{Li}, \mathrm{M}$., Xu, K., Watanabe, M., and Chen, Z.: Long-term variations in dissolved silicate, nitrogen, and phosphorus flux from the Yangtze River into the East China Sea and impacts on estuarine ecosystem, Estuar. Coast. Shelf S., 71, 3-12, 2007.

Liu, D., Sun, J., Zhang, J., and Liu, G.: Response of the diatom flora in Jiaozhou Bay, China to environmental changes during the last century, Mar. Micropaleontol., 66, 279-290, 2008.

Liu, P., Yu, Y., and Liu, C.: Studies on the situation of pollution and countermeasures of control of the oceanic environment in Zhoushan fishing ground-the largest fishing ground in China, Mar. Pollut. Bull., 23, 281-288, 1991.

Liu, Z. L., Ning, X. R., and Cai, Y. M.: Primary productivity and standing stock of the phytoplankton in the Hangzhou Bay to the Zhoushan Fishing Ground during autumn and its tributaries, Acta Oceanol. Sin., 23, 93-99, 2001 (in Chinese).

Marshall, H. G., Lane, M. F., and Nesius, K. K.: Long-term phytoplankton trends and related water quality trends in the lower Chesapeake Bay, Virginia, USA, Environ. Monit. Assess., 81, 349-360, 2003.

McQuoid, M. R. and Nordberg, K.: The diatom Paralia sulcata as an environmental indicator species in coastal sediments, Estuar. Coast. Shelf S., 56, 339-354, 2003.

Miao, Y. T. and Yu, H. H.: Spatial and temporal variations of water type mixing characteristic in the East China Sea, in: Transactions of Scientific Survey on Kuroshio Current, edited by: Su, J. L., Chen, Z. S., and Yu, G. S., Ocean Press, Beijing, 193-203, 1991.

20

Mortlock, R. A. and Froelich, P. N.: A simple method for the rapid-determination of biogenic opal in pelagic marine sediments, Deep-Sea Res. Pt. I, 36, 1415-1426, 1989.

Ning, X., Liu, Z., Cai, Y., and Fang, M.: Physicobiological oceanographic remote sensing of the East China Sea: satellite and in situ observations, J. Geophys. Res.-Oceans, 103, 2162321635, 1998.

Ning, X. R., Shi, J. X., Liu, Z. L., Chen, Z. Y., and Liu, Z. S.: Distribution features of Chl $a$ and ATP in the Changjiang River and the Hangzhou Bay and coast of Zhejiang Province, Acta Oceanol. Sin., 26, 96-106, 1986 (in Chinese).

Nixon, S. W.: Coastal marine eutrophication - a definition, social causes, and future concerns, Ophelia, 41, 199-219, 1995.

so Olli, K., Klais, R., Tamminen, T., Ptacnik, R., and Andersen, T.: Long term changes in the Baltic Sea phytoplankton community, Boreal Environ. Res., 16, 3-14, 2011.

\section{BGD}

$9,6261-6291,2012$

\section{Historical records of eutrophication}

F. Cheng et al.

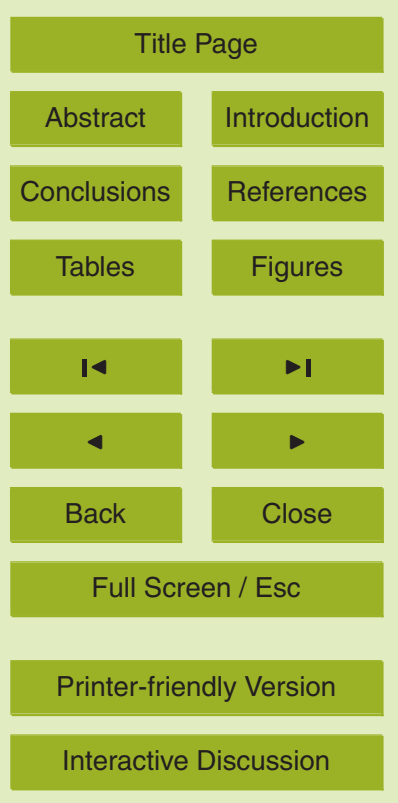


Parsons, M. L., Dortch, Q., and Turner, R. E.: Sedimentological evidence of an increase in Pseudo-nitzschia (Bacillariophyceae) abundance in response to coastal eutrophication, Limnol. Oceanogr., 47, 551-558, 2002.

Parsons, M. L., Dortch, Q., Turner, R. E., and Rabalais, N. R.: Reconstructing the development 5 of eutrophication in Louisiana salt marshes, Limnol. Oceanogr., 51, 534-544, 2006.

Pinturier-Geiss, L., Mejanelle, L., Dale, B., and Karlsen, D. A.: Lipids as indicators of eutrophication in marine coastal sediments, J. Microbiol. Meth., 48, 239-257, 2002.

$\mathrm{Pu}, \mathrm{X} . \mathrm{M} ., \mathrm{Wu}, \mathrm{Y}$. L., and Zhang, Y. S.: Nutrient limitation of phytoplankton in the Changjiang estuary: condition of nutrient limitation in spring, Acta Oceanol. Sin., 23, 57-65, 2001 (in 10 Chinese).

Qi, Y. Z.: Red Tides in China Coastal Areas, Science Press, Beijing, 348 pp., 2003.

Ronnberg, C. and Bonsdorff, E.: Baltic Sea eutrophication: area-specific ecological consequences, Hydrobiologia, 514, 227-241, 2004.

Ryther, J. H. and Dunstan, W. M.: Nitrogen, phosphorus, and eutrophication in the coastal marine environment, Science, 1008-1013, 1971.

Scherader, H. J. and Gersonde, R.: Diatoms and silicoflagellates, Utr. Micropaleontol. Bull., 19, 439-444, 1978.

Shannon, C. E. and Weaver, W.: The Mathematical Theory of Communication, University of Illinois Press, Urbana IL, 1949.

Shen, H., Xu, R., and Wang, G. L.: Studies on phytoplankton in waters adjacent to islands of Shanghai., Mar. Sci. Bull., 14, 26-37, 1995 (in Chinese).

Shen, Z.-L. and Liu, Q.: Nutrients in the Changjiang River, Environ. Monit. Assess., 153, 27-44, 2009.

Smith, V. H.: Eutrophication of freshwater and coastal marine ecosystems a global problem, Environ. Sci. Pollut. Res., 10, 126-139, 2003.

State Ocean Administration: Bulletin of Marine Environmental Quality of China, Beijing, 2009.

Stoermer, E. F. and Smol, J. P.: The Diatoms: Applications for Environmental and Earth Sciences, Cambridge University Press, Cambridge, 1999.

Terbraak, C. J. F. and Verdonschot, P. F. M.: Canonical correspondence-analysis and related multivariate methods in aquatic ecology, Aquat. Sci., 57, 255-289, 1995.

Tian, R. C., Hu, F. X., and Martin, J. M.: Summer nutrient fronts in the Changjiang (Yantze River) estuary, Estuar. Coast. Shelf S., 37, 27-41, 1993.

\section{BGD}

9, 6261-6291, 2012

\section{Historical records of eutrophication}

F. Cheng et al.

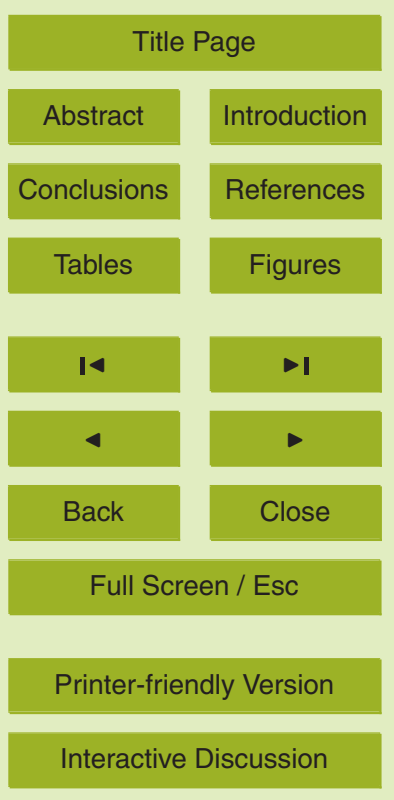


Tibby, J. and Taffs, K. H.: Palaeolimnology in eastern and southern Australian estuaries, J. Paleolimnol., 46, 503-510, 2011.

Turner, B. L.: Chemistry and dynamics of organic phosphorus in the environment, Abstr. Pap. Am. Chem. S., 238, 591-591, 2009.

5 Turner, B. L., Paphazy, M. J., Haygarth, P. M., and McKelvie, I. D.: Inositol phosphates in the environment, Philos. T. Roy. Soc. B, 357, 449-469, 2002.

Voß, M. and Struck, U.: Stable nitrogen and carbon isotopes as indicator of eutrophication of the Oder river (Baltic Sea), Mar. Chem., 59, 35-49, 1997.

Wang, B.: Cultural eutrophication in the Changjiang (Yangtze River) plume: history and perspective, Estuar. Coast. Shelf S., 69, 471-477, 2006.

Wang, K. F., Jiang, H., Zhi, C. Y., Tao, M. H., and Wang, H. G.: Study on the relationship between diatom assemblage in surface sediments and the environment in the East China Sea., Acta Micropalaeontol. Sin., 18, 379-384, 2001 (in Chinese).

Wang, K. F., Zhi, C. Y., and Tao, M. H.: Discovery of diatom and analysis of paleoenvironment 15 of the late quaternary on the margin of East China Sea (section of South Zhejiang), Acta Micropalaeontol. Sin., 20, 350-357, 2003 (in Chinese).

Wang, Z. H., Shi, X. Y., Zhang, C., Liang, S. K., and Wang, L. S.: Primary study on characteristics of distribution of chlorophyll-a in the Yellow Sea and East China Sea, Progress in Fishery Science, 30, 120-126, 2009 (in Chinese).

20 Zhou, M. J., Shen, Z. L., and Yu, R. C.: Responses of a coastal phytoplankton community to increased nutrient input from the Changjiang (Yangtze) River, Cont. Shelf Res., 28, 14831489, 2008.

Zhou, W. H., Huo, W. Y., Yuan, X. C., and Yin, K. D.: Distribution features of chlorophyll a and primary productivity in high frequency area of red tide in East China Sea during spring, Chin. J. Appl. Ecol., 14, 1055-1059, 2003 (in Chinese).

Zhu, M. Y., Li, R. X., and Wang, F.: Research on Red tides in China, SCOR-IOC red tide working group Qingdao, 24-41, 1995.

Zimmerman, A. R., and Canuel, E. A.: A geochemical record of eutrophication and anoxia in Chesapeake Bay sediments: anthropogenic influence on organic matter composition, Mar.

30 Chem., 72, 77-77, 2000.

Zimmerman, A. R. and Canuel, E. A.: Sediment geochemical records of eutrophication in the mesohaline Chesapeake Bay, Limnol. Oceanogr., 47, 1084-1093, 2002.

BGD

9, 6261-6291, 2012

\section{Historical records of eutrophication}

F. Cheng et al.

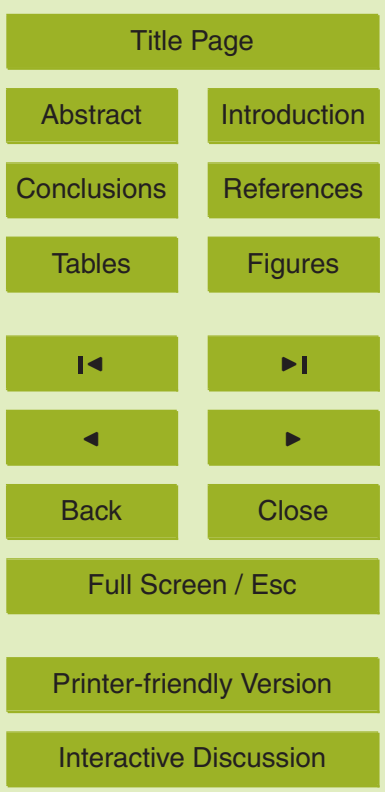


BGD

9, 6261-6291, 2012

\section{Historical records of} eutrophication

F. Cheng et al.

Table 1. Site location of Chl a concentration $\left(\mathrm{mg} \mathrm{m}^{-3}\right)$ in Changjiang River estuary and its adjacent sea from 1980-2006.

\begin{tabular}{lcc}
\hline Time & Location & Refences \\
\hline 1984.8 & $28-32^{\circ} \mathrm{N}$ west to $124^{\circ} \mathrm{E}$ & Ning et al. (1986) \\
1988.8 & $30^{\circ} 30^{\prime}-31^{\circ} 50^{\prime}$ west to $124^{\circ} 30^{\prime} \mathrm{E}$ & Shen and Hu (1995) \\
1995.9 & $30^{\circ} 30^{\prime}-31^{\circ} 30^{\prime} 121^{\circ} 30^{\prime}-123^{\circ} 38^{\prime} \mathrm{E}$ & Liu et al. (2001) \\
2002.8 & $29^{\circ} 00^{\prime}-32^{\circ} 00^{\prime} 122^{\circ} 00^{\prime}-123^{\circ} 30^{\prime} \mathrm{E}$ & Zhou et al. (2003) \\
2006.8 & $25^{\circ} 00^{\prime}-35^{\circ} 48^{\prime} 120^{\circ} 00^{\prime}-126^{\circ} 00^{\prime} \mathrm{E}$ & Wang et al. (2009) \\
\hline
\end{tabular}

\section{Title Page}

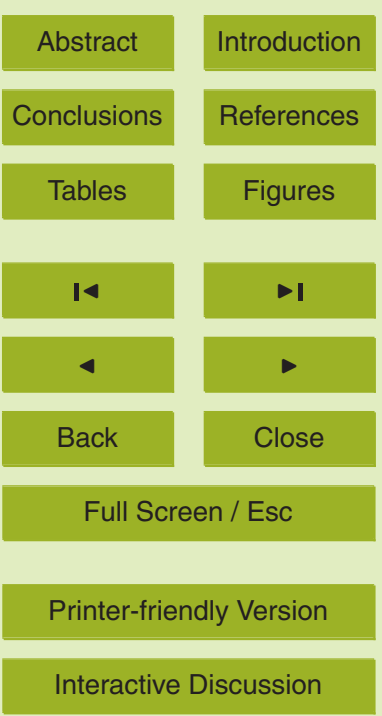




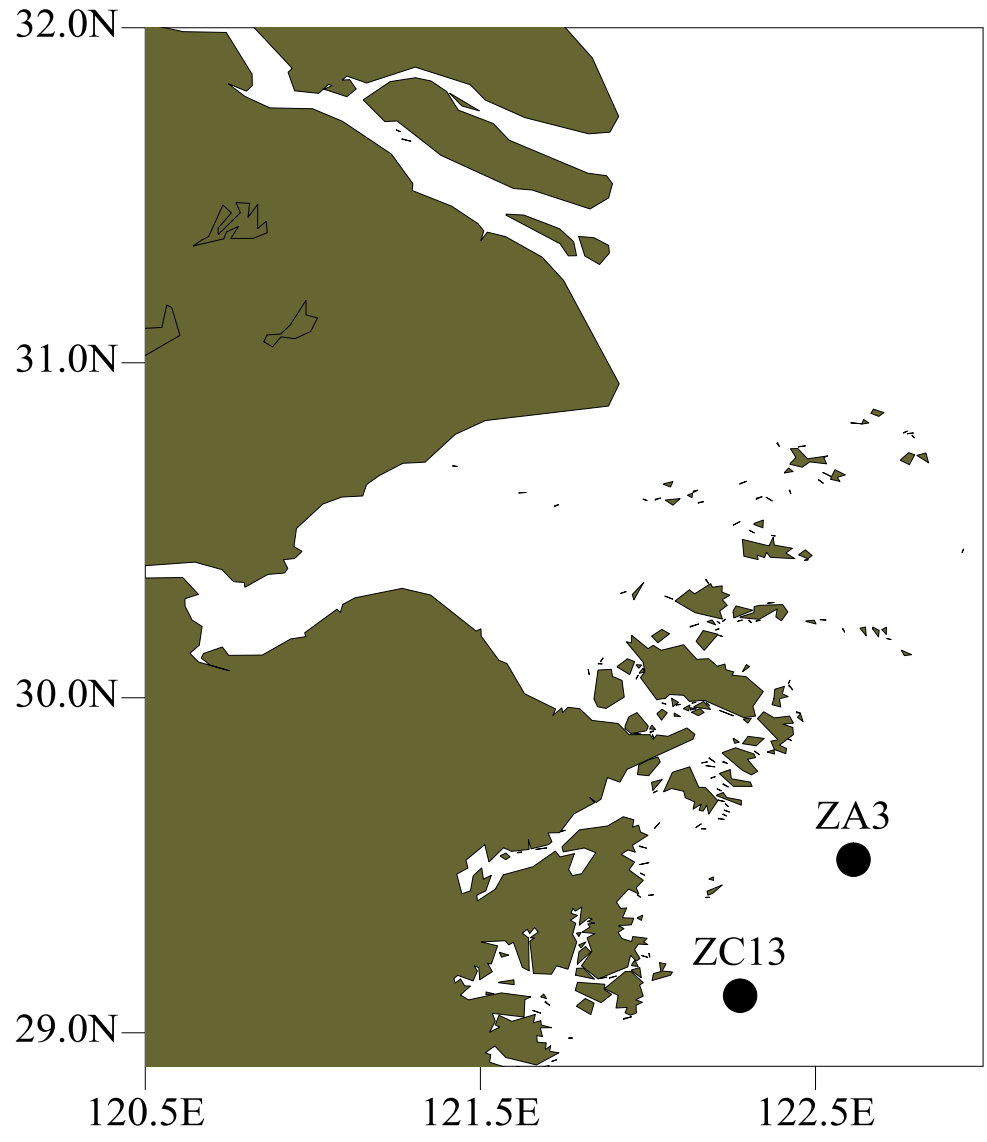

\section{BGD}

9, 6261-6291, 2012

Historical records of eutrophication

F. Cheng et al.

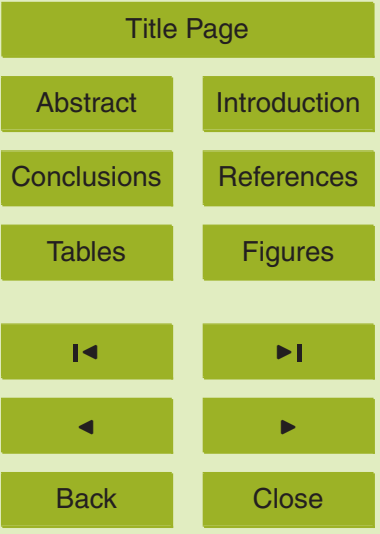

Full Screen / Esc

Printer-friendly Version

Interactive Discussion

Fig. 1. Map of Changjiang (Yangtze) River estuary and its adjacent East China Sea showing core collection locations. 
A Excess ${ }^{210} \mathrm{~Pb}$ Activity (ln (dpm/g))

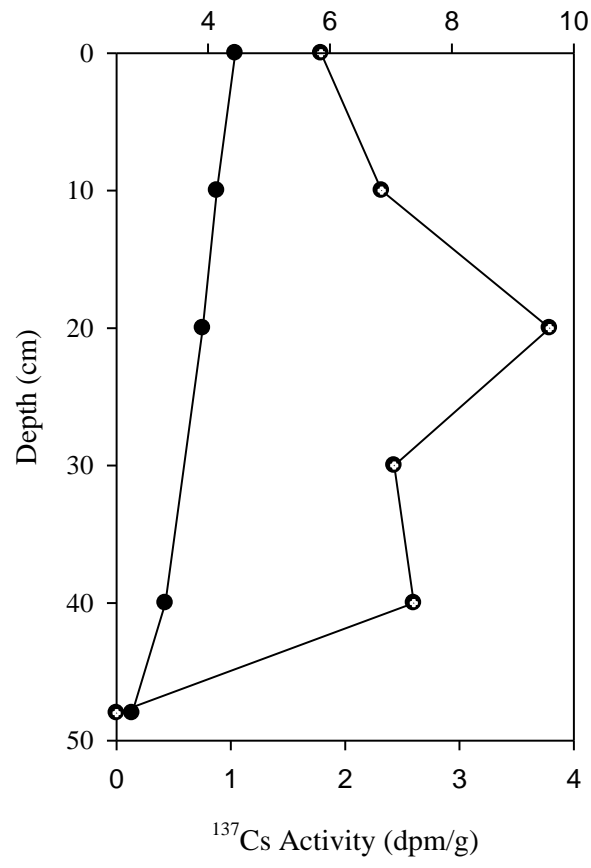

$$
\begin{aligned}
& \longrightarrow-{ }^{137} \mathrm{Cs} \text { Activity } \\
& \longrightarrow-\text { Excess }{ }^{210} \mathrm{~Pb} \text { Activity }
\end{aligned}
$$

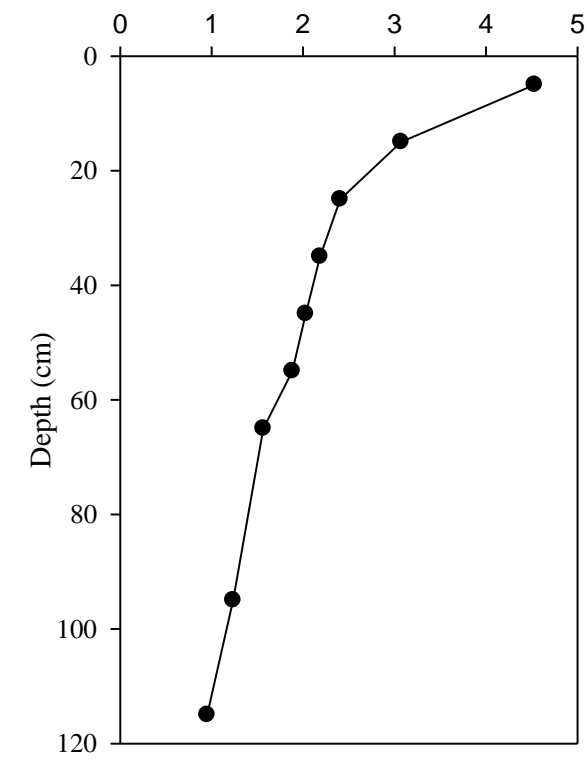

$\longrightarrow$ Excess ${ }^{210} \mathrm{~Pb}$ Activity

Fig. 2. Depth profiles of excess ${ }^{210} \mathrm{~Pb}$ and ${ }^{137} \mathrm{Cs}$ activity in cores ZC13 (A) and ZA3 (B).
BGD

9, 6261-6291, 2012

Historical records of eutrophication

\section{F. Cheng et al.}

Title Page

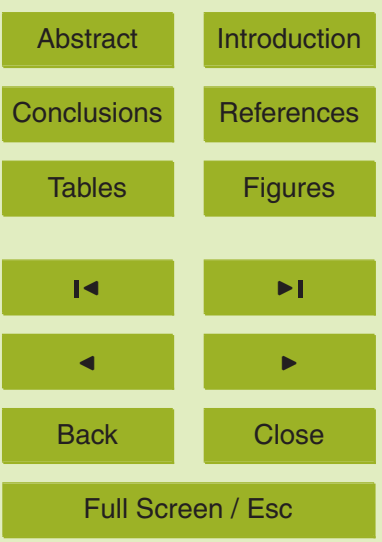

Printer-friendly Version

Interactive Discussion 


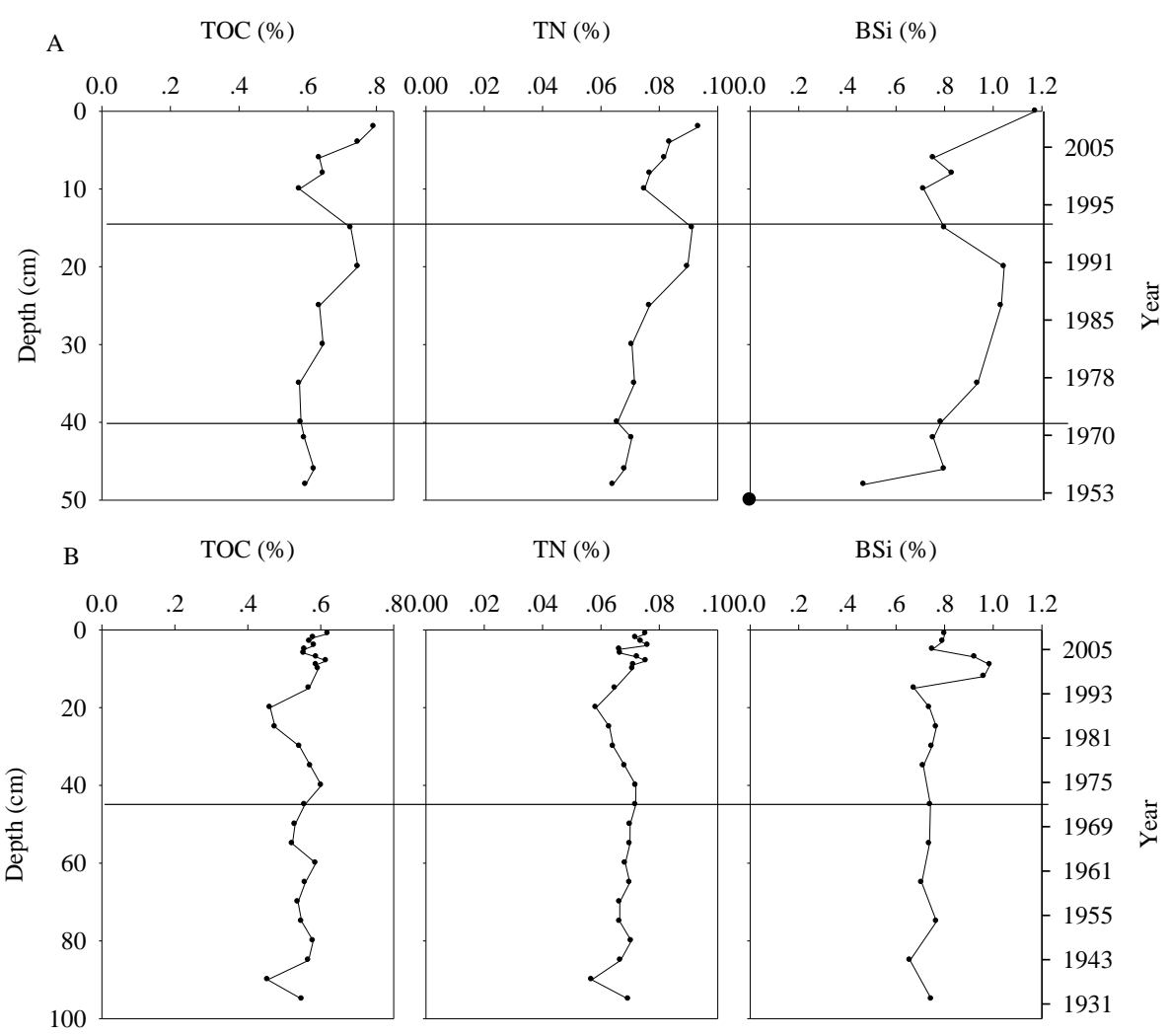

BGD

9, 6261-6291, 2012

Historical records of eutrophication

F. Cheng et al.

Title Page

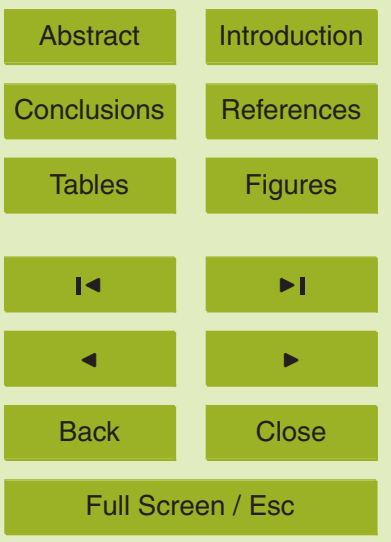

Printer-friendly Version

Fig. 3. Core profiles of $\mathrm{BSi}, \mathrm{TOC}$ and $\mathrm{TN}$ in cores $\mathrm{ZC13}$ (A) and ZA3 (B).

Interactive Discussion 
BGD

9, 6261-6291, 2012

\section{Historical records of eutrophication}
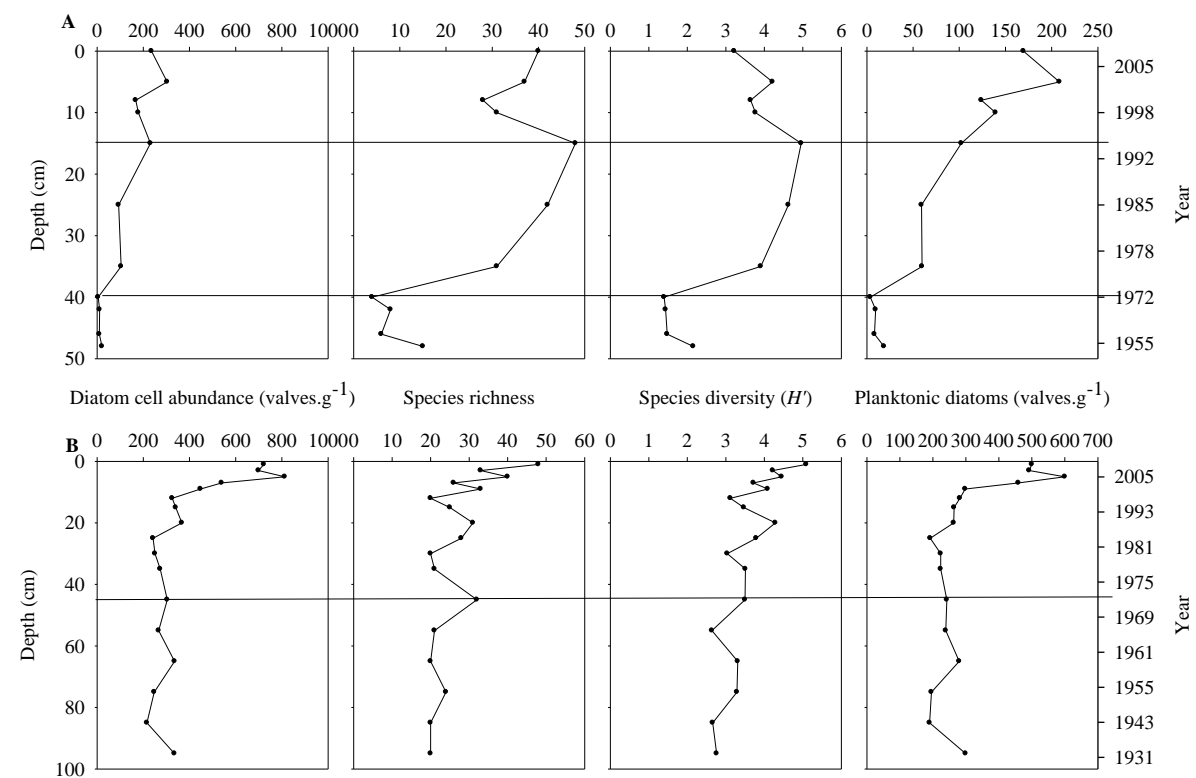

Fig. 4. Core profiles of diatom cell abundance $\left(N_{\mathrm{a}}\right)$, species richness $(S)$, diversity $\left(H^{\prime}\right)$ and planktonic diatom abundance in cores ZC13 (A) and ZA3 (B).

\section{F. Cheng et al.}

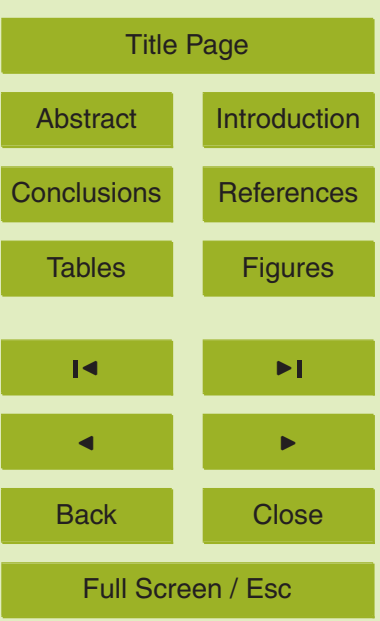

Printer-friendly Version

Interactive Discussion 


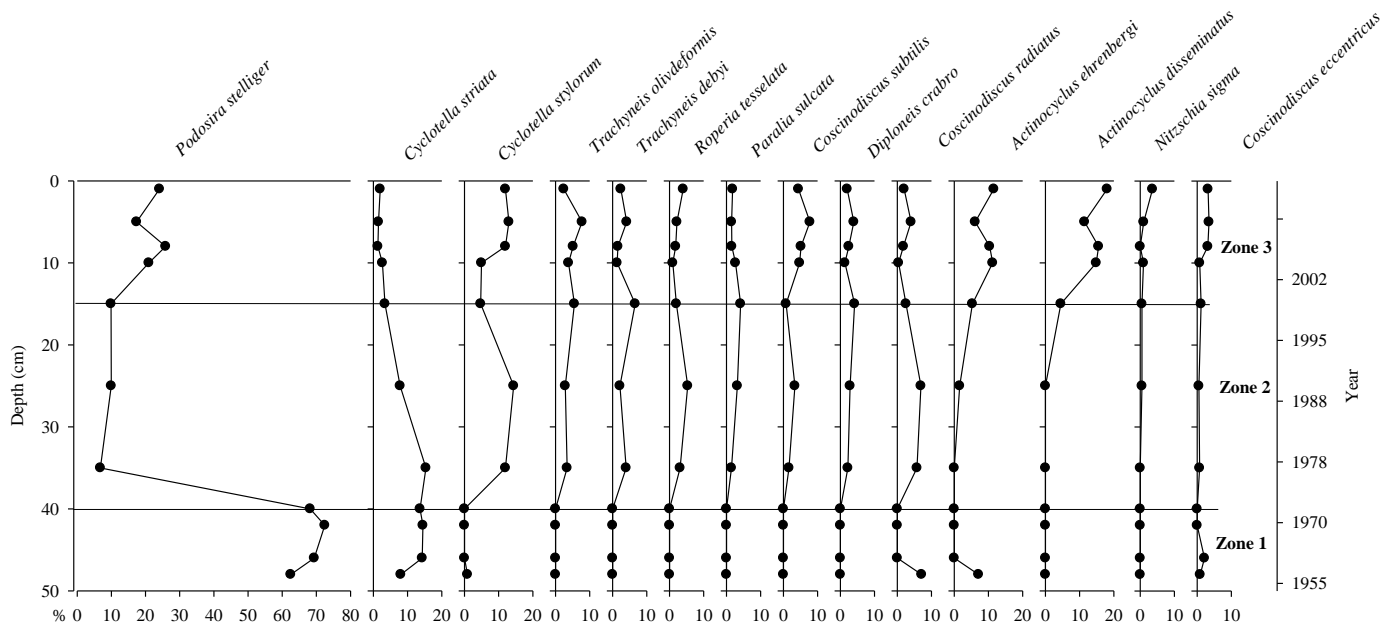

Fig. 5. Diatom diagram of selected common species in relative abundance $\left(N_{\mathrm{r}}\right)$ in the core ZC13.
BGD

9, 6261-6291, 2012

\section{Historical records of} eutrophication

\section{F. Cheng et al.}

Title Page

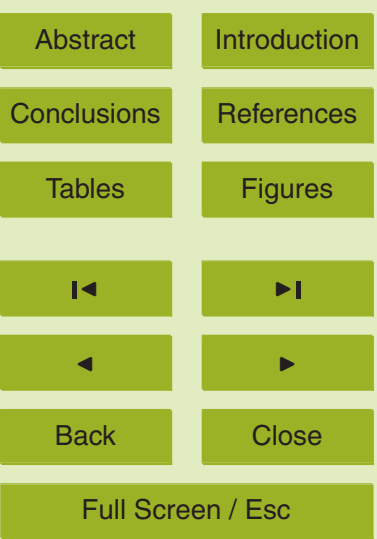

Printer-friendly Version

Interactive Discussion 


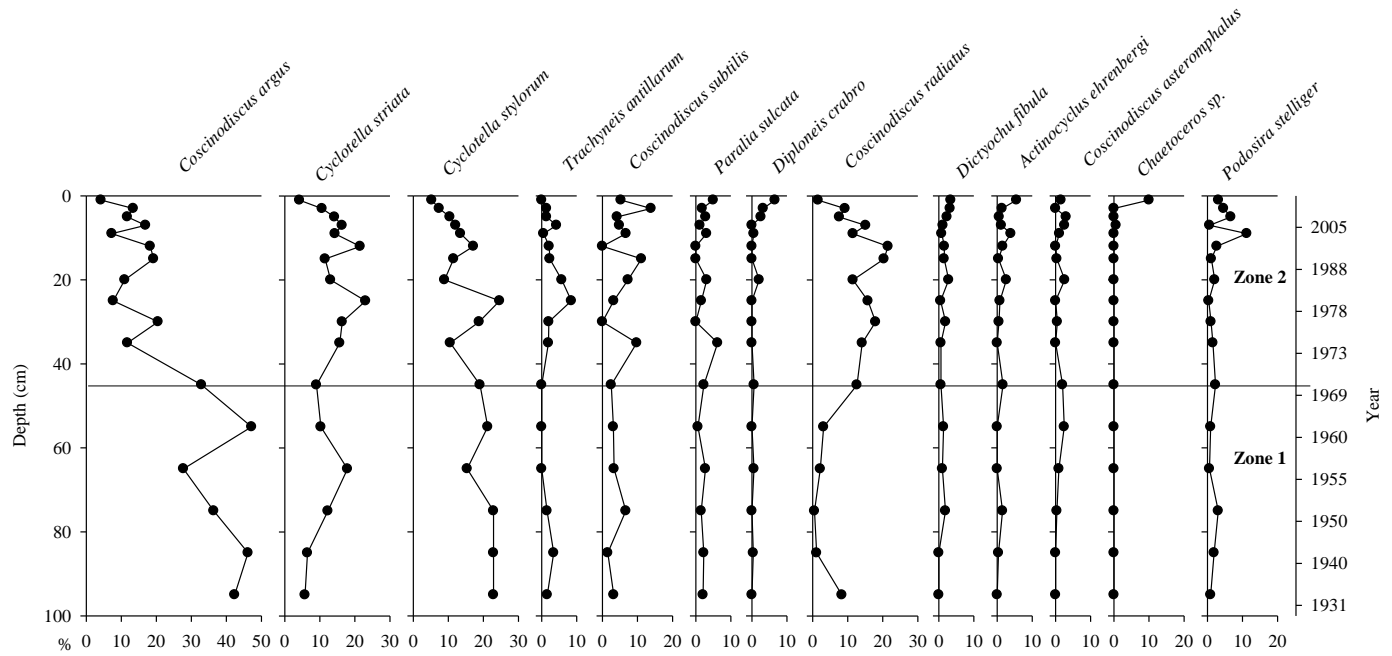

Fig. 6. Diatom diagram of selected common species in relative abundance $\left(N_{r}\right)$ in the core ZA3.
BGD

9, 6261-6291, 2012

Historical records of eutrophication

F. Cheng et al.

Title Page

\begin{tabular}{|c|c|}
\hline Abstract & Introduction \\
\hline Conclusions & References \\
\hline Tables & Figures \\
\hline I & \\
\hline & \\
\hline Back & Close \\
\hline Full Screen / Esc
\end{tabular}

Printer-friendly Version

Interactive Discussion 
$\mathbf{A}$

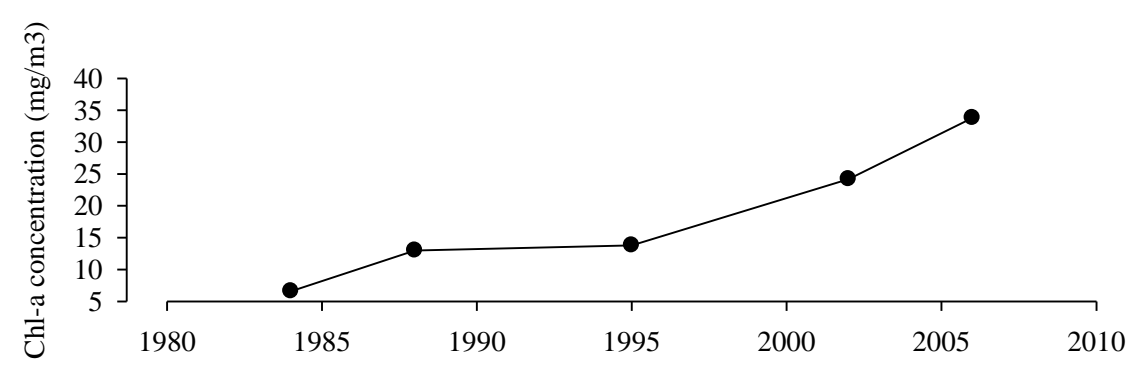

B

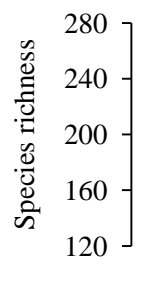

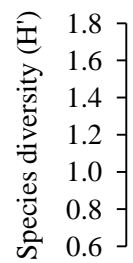

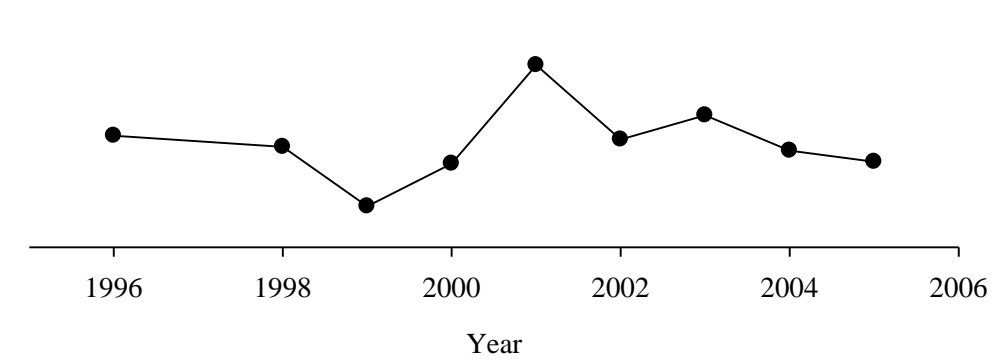

Fig. 7. Profiles of maximum Chl a concentration $\left(\mathrm{mg} \mathrm{m}^{-3}\right)$ from $1980-2006$ (A) and annual means in phytoplankton diversity factors from 1996 - 2005 (B) (Wang et al., 2009; Zhou et al., 2003; Shen et al., 1995; Ning et al., 1986; Liu et al., 2001).

\section{BGD}

\section{$9,6261-6291,2012$}

\section{Historical records of eutrophication}

\section{F. Cheng et al.}

Title Page

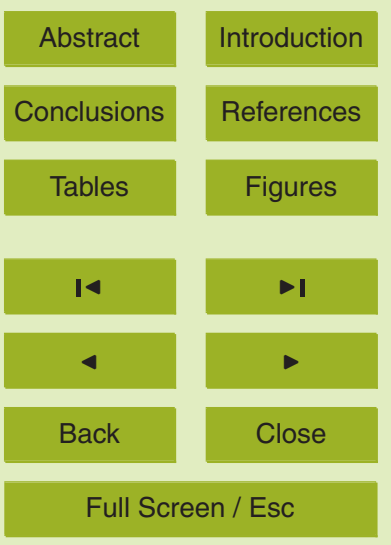

Printer-friendly Version

Interactive Discussion 